\title{
The spatial distribution of mineral dust and its shortwave radiative forcing over North Africa: modeling sensitivities to dust emissions and aerosol size treatments
}

\author{
C. Zhao ${ }^{1}$, X. Liu ${ }^{1}$, L. R. Leung ${ }^{1}$, B. Johnson ${ }^{2}$, S. A. McFarlane ${ }^{1}$, W. I. Gustafson Jr. ${ }^{1}$, J. D. Fast ${ }^{1}$, and R. Easter ${ }^{1}$ \\ ${ }^{1}$ Atmospheric Science and Global Change Division, Pacific Northwest National Laboratory, Richland, WA, USA \\ ${ }^{2}$ Met Office, Exeter, UK
}

Received: 4 March 2010 - Published in Atmos. Chem. Phys. Discuss.: 16 April 2010

Revised: 16 April 2010 - Accepted: 14 September 2010 - Published: 20 September 2010

\begin{abstract}
A fully coupled meteorology-chemistry-aerosol model (WRF-Chem) is applied to simulate mineral dust and its shortwave (SW) radiative forcing over North Africa. Two dust emission schemes (GOCART and DUSTRAN) and two aerosol models (MADE/SORGAM and MOSAIC) are adopted in simulations to investigate the modeling sensitivities to dust emissions and aerosol size treatments. The modeled size distribution and spatial variability of mineral dust and its radiative properties are evaluated using measurements (ground-based, aircraft, and satellites) during the AMMA SOP0 campaign from 6 January to 3 February of 2006 (the SOP0 period) over North Africa. Two dust emission schemes generally simulate similar spatial distributions and temporal evolutions of dust emissions. Simulations using the GOCART scheme with different initial (emitted) dust size distributions require $\sim 40 \%$ difference in total emitted dust mass to produce similar SW radiative forcing of dust over the Sahel region. The modal approach of MADE/SORGAM retains $25 \%$ more fine dust particles (radius $<1.25 \mu \mathrm{m}$ ) but $8 \%$ less coarse dust particles (radius $>1.25 \mu \mathrm{m}$ ) than the sectional approach of MOSAIC in simulations using the same sizeresolved dust emissions. Consequently, MADE/SORGAM simulates $11 \%$ higher AOD, up to $13 \%$ lower SW dust heating rate, and $15 \%$ larger (more negative) SW dust radiative forcing at the surface than MOSAIC over the Sahel region. In the daytime of the SOP0 period, the model simulations show that the mineral dust heats the lower atmosphere with an average rate of $0.8 \pm 0.5 \mathrm{~K} \mathrm{day}^{-1}$ over the Niamey vicinity and $0.5 \pm 0.2 \mathrm{~K} \mathrm{day}^{-1}$ over North Africa and reduces the downwelling SW radiation at the surface by up to $58 \mathrm{~W} \mathrm{~m}^{-2}$ with
\end{abstract}

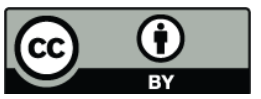

Correspondence to: C. Zhao

(chun.zhao@pnl.gov) an average of $22 \mathrm{~W} \mathrm{~m}^{-2}$ over North Africa. This highlights the importance of including dust radiative impact in understanding the regional climate of North Africa. When compared to the available measurements, the WRF-Chem simulations can generally capture the measured features of mineral dust and its radiative properties over North Africa, suggesting that the model is suitable for more extensive simulations of dust impact on regional climate over North Africa.

\section{Introduction}

Mineral dust, one of the most abundant aerosol species in the atmosphere in terms of mass, has important climatic effect through its influence on solar and terrestrial radiation and the radiative and physical properties of clouds (e.g., Sokolik et al., 1998; Ginoux et al., 2001; Ramanathan et al., 2001; Lau et al., 2009). The Sahara desert over North Africa is the largest source of mineral dust in the world; mineral dust can modify the hydrological cycle over North Africa and modulate the tropical North Atlantic temperature (e.g., Miller et al., 2004; Evan et al., 2009; Lau et al., 2009). Since finer dust particles can be lifted to high altitudes, where they are transported over long distances (often thousands of kilometers) from the source regions, Saharan dust can also play an important role in modifying climate on the global scale, when transported northward across the Mediterranean region up to central and northern Europe, or westward across the Atlantic Ocean occasionally to the eastern coast of the United States (e.g., Moulin et al., 1997; Miller et al., 2004; Chin et al., 2007; Flaounas et al., 2009).

Published by Copernicus Publications on behalf of the European Geosciences Union. 
Despite the climatic importance of mineral dust on both regional and global scales, modeling of size-resolved spatial distribution of mineral dust and its radiative forcing remains uncertain and challenging, as highlighted by IPCC (2007). The large uncertainty in simulating mineral dust and its radiative forcing mainly resides in the estimation of the sizeresolved dust emissions in the source regions, the treatment of aerosols in models (e.g., representation of aerosol size distributions), and the determination of optical properties of mineral dust (e.g., Ginoux et al., 2001; Zender et al., 2003; Kalashnikova et al., 2004; Balkanski et al., 2007; Darmenova et al., 2009; McConnell et al., 2010). This study mainly focuses on the first two sources of uncertainty in modeling mineral dust and its radiative forcing.

Dust emission fluxes are widely modeled through parameterizations of suspension (by which soil particles are suspended into the air), saltation (sand blasting) and creeping (slow progression of soil and rock) processes associated with wind erosion (Bagnold et al., 1941). The initial size distribution of emitted dust is either based on soil texture data that are not always available and have large uncertainty due to spatial heterogeneity, or on measurements of the background dust in the atmosphere, which may not be representative of the dust in its emission fluxes because the lifetime of dust particles is size dependent (e.g., d'Almeida and Schutz, 1983; Tegen et al., 1997; Ginoux et al., 2001; Shaw et al., 2008). The size distributions of dust particles in the atmosphere are mainly represented using modal or sectional approaches in aerosol models. A modal approach represents the size distribution of aerosols by several overlapping intervals, called modes, normally assuming a log-normal distribution within each mode, while a sectional approach represents the size distribution of aerosols by several discrete size bins, which are defined by their lower and upper dry particle diameters. Generally speaking, a modal approach is less accurate because of its assumption of log-normal distribution and limited number of modes, but it is computationally cheaper than a sectional approach that uses more bins.

In order to constrain model simulations of mineral dust and its radiative forcing, extensive measurements in dust source regions are needed. One such dataset is from the Dust and Biomass burning Experiment (DABEX), which occurred from 13 January to 3 February 2006 in the vicinity of Niamey in North Africa (Haywood et al., 2008). Aircraft measurements from DABEX, complemented by ground-based remote sensing measurements at the Aerosol Robotic Network (AERONET) sun-photometer sites (Dubovik and King, 2000) and the U.S. Department of Energy's Atmospheric Radiation Measurements (ARM) Program Mobile Facility (AMF) (located at the Niamey airport) (Miller and Slingo, 2007), have been used by previous studies to investigate the formation, transport, and temporal and spatial distribution of mineral dust and its radiative forcing during various dust outbreak cases over North Africa (e.g., Greed et al., 2008; Milton et al., 2008; Myhre et al., 2008; Tulet et al., 2008).
The Weather Research and Forecasting (WRF) model (Skamarock et al., 2008) has been used for regional air quality and climate studies (e.g., Fast et al., 2006 and 2009; Leung et al., 2006; Wang and Liu, 2009; Qian et al., 2009; Zhang et al., 2009). WRF-Chem is a version of WRF that also simulates trace gases and particulates simultaneously with the meteorological fields (Grell et al., 2005). Since the dust radiative effect on climate is likely to be especially important on the regional scale (e.g., Nickovic et al., 2001; Gong et al., 2003; Zakey et al., 2006), we use two dust emission schemes that were recently implemented in WRF-Chem to investigate the regional radiative forcing of mineral dust and its sensitivities to size-resolved dust emissions. One scheme was developed by Ginoux et al. (2001) for the Goddard Global Ozone Chemistry Aerosol Radiation and Transport (GOCART) model (referred to as GOCART hereafter), which has been widely used in regional and global models. The other was developed by Shaw et al. (2008) for the DUST TRANsport model (DUSTRAN; Allwine et al., 2006) (referred to as DUSTRAN hereafter). In addition, both schemes are coupled with two aerosol models, MADE/SORGAM (modal approach) and MOSAIC (sectional approach), to investigate modeling sensitivities to the representation of aerosol size distributions within the framework of WRF-Chem.

As the first step in our studying the regional climatic effect of mineral dust, the objective of this study is two-fold: (1) to evaluate the performance of WRF-Chem in simulating mineral dust and its radiative forcing over North Africa, and (2) to quantify modeling sensitivities to the representations of dust emissions and aerosol size distributions. The paper is organized as follows. Sections 2 and 3 detail the WRF-Chem model and the observations used in this study. The sizeresolved spatial distribution of mineral dust and its modeling sensitivities to dust emissions and aerosol size treatments are analyzed in Sect. 4. The shortwave (SW) radiative forcing of mineral dust and its modeling sensitivities to model parameterizations are investigated in Sect. 5. The paper concludes in Sect. 6.

\section{Model description}

\subsection{WRF-Chem}

WRF-Chem, a version of WRF (Skamarock et al., 2005), simulates trace gases and particulates simultaneously with the meteorological fields (Grell et al., 2005). The WRFChem model is initially configured with the RADM2 (Regional Acid Deposition Model 2) photochemical mechanism (Stockwell et al., 1990) and the MADE/SORGAM (Modal Aerosol Dynamics Model for Europe (MADE) and Secondary Organic Aerosol Model (SORGAM)) aerosol model (Ackermann et al., 1998; Schell et al., 2001). The CBM$\mathrm{Z}$ (Carbon Bond Mechanism) photochemical mechanism 
(Zaveri and Peters, 1999) and MOSAIC (Model for Simulating Aerosol Interactions and Chemistry) aerosol model (Zaveri et al., 2008) were implemented by Fast et al. (2006) into WRF-Chem, which also includes more complex treatments of aerosol radiative properties and photolysis rates. MADE/SORGAM in WRF-Chem uses the modal approach with three modes (Aitken, accumulation, and coarse modes) to represent the aerosol size distribution, while MOSAIC uses a sectional approach where the aerosol size distribution is divided into discrete size bins. Eight size bins (0.039-0.078 $\mu \mathrm{m}, 0.078-0.156 \mu \mathrm{m}, 0.156-0.312 \mu \mathrm{m}, 0.312-$ $0.625 \mu \mathrm{m}, 0.625-1.25 \mu \mathrm{m}, 1.25-2.5 \mu \mathrm{m}, 2.5-5.0 \mu \mathrm{m}, 5.0-$ $10.0 \mu \mathrm{m}$ dry diameter) are employed in this study as in Fast et al. (2006, 2009). Each size bin (or mode) is assumed to be internally mixed so that all particles within a size bin (or mode) are assumed to have the same chemical composition. In both of the MADE/SORGAM and MOSAIC aerosol models, aerosols are mainly composed of sulfate, nitrate, ammonium, organic matters $(\mathrm{OM})$, black carbon $(\mathrm{BC})$, water, sea salt and mineral dust. The aerosol optical properties such as extinction, single-scattering albedo, and the asymmetry factor for scattering are computed as a function of wavelength and three-dimensional position. Each chemical constituent of the aerosol is associated with a complex index of refraction. The refractive index is calculated by volume averaging for each size bin (or mode), and Mie theory is used to estimate the extinction efficiency $\left(Q_{\mathrm{e}}\right)$ and the scattering efficiency $\left(Q_{\mathrm{s}}\right)$. To efficiently compute the $Q_{\mathrm{e}}$ and $Q_{\mathrm{s}}$, WRF-Chem has used a methodology described by Ghan et al. (2001), which performs full Mie calculations once first to obtain seven sets of Chebyshev expansion coefficients, and later on, the full Mie calculations are skipped and the $Q_{\mathrm{e}}$ and $Q_{\mathrm{s}}$ are calculated using bilinear interpolation over the seven sets of the stored Chebyshev coefficients. A detailed description of the computation of aerosol optical properties in WRF-Chem can be found in Fast et al. (2006) and Barnard et al. (2010). The version 3.1.1 of WRF-Chem is used in this study, but it is updated with the capability of using the same dry deposition treatment (Binkowski and Shankar, 1995; Ackermann et al., 1998) for the MADE/SORGAM and MOSAIC aerosol models, which will be available in the next released version of WRF-Chem.

In this study, WRF-Chem is configured to cover North Africa $\left(36.15^{\circ} \mathrm{W}-40.15^{\circ} \mathrm{E}, 9.2^{\circ} \mathrm{S}-37.0^{\circ} \mathrm{N}\right)$ with $200 \times 150$ grid points, a $36 \mathrm{~km}$ horizontal resolution centering at $\mathrm{Ni}-$ amey (Niger) $\left(2.0^{\circ} \mathrm{E}, 13.6^{\circ} \mathrm{N}\right)$, and 35 vertical layers to $10 \mathrm{hPa}$. The Noah land surface model and Mellor-YamadaJanjic Planetary Boundary Layer (PBL) scheme are used. Meteorological fields are assimilated with the lateral boundary and initial conditions from NCAR/NCEP Global reanalysis data. Chemical lateral boundary conditions are from the default profiles in WRF-Chem, which are the same as those in the work by McKeen et al. (2002) and are based on averages of mid-latitude aircraft profiles from several field studies over the eastern Pacific Ocean. The simula- tion is conducted by reinitializing meteorological conditions every 5 days with NCAR/NCEP reanalysis data and including an overlap period of one day for each simulation block for meteorological spin up, starting from 1 January 2006 to 5 February 2006. The re-initialization of meteorological conditions can reduce the bias in meteorological simulations. Only the simulated results from 6 January 2006 to 5 February 2006 (referred to as the simulation period hereafter) are used in the analysis to minimize the impact from the chemical initial conditions. Only the simulated results at the $170 \times 120$ interior points $\left(28.9^{\circ} \mathrm{W}-32.9^{\circ} \mathrm{E}, 5.0^{\circ} \mathrm{S}-\right.$ $32.1^{\circ} \mathrm{N}$ ) of the horizontal domain with $200 \times 150$ grid points are used for analysis to minimize the potential spurious anomalies from the lateral boundary conditions. Anthropogenic emissions are obtained from the Reanalysis of the TROpospheric (RETRO) chemical composition inventories (http://retro.enes.org/index.shtml). Biomass burning emissions are obtained from the Global Fire Emissions Database, Version 2 (GFEDv2.1) with 8-day temporal resolution (Randerson et al., 2005) and vertically distributed following injection heights suggested by Dentener et al. (2006) for the Aerosol InterComparison project (AeroCom), because of insufficient information available to perform plume rise calculations over North Africa. In this study, the Goddard shortwave radiation scheme and Lin's microphysics scheme are used to represent the aerosol direct and indirect effects (1st and 2nd) as described in Gustafson et al. (2007), respectively. Since aerosol direct effect on longwave radiation has not yet been implemented in WRF-Chem during this study and the simulated cloud optical depth (figure not shown) is very low $(<1)$ over the most regions of continent during the simulation period, this study focuses on the analysis of the SW radiative forcing of mineral dust.

\subsection{Dust emission}

Two dust emission schemes, GOCART and DUSTRAN, are coupled with both the MADE/SORGAM and MOSAIC aerosol models within the framework of WRF-Chem to study the modeling sensitivities to dust emission schemes. As described in Ginoux et al. (2001), the GOCART scheme calculates the dust emission flux $G$ as

$$
G=C S s_{\mathrm{p}} u_{10 \mathrm{~m}}^{2}\left(u_{10 \mathrm{~m}}-u_{\mathrm{t}}\right)
$$

where $C$ is an empirical proportionality constant, $S$ is a source function which defines the potential dust source regions and comprises surface factors, such as vegetation and snow cover, $s_{\mathrm{p}}$ is a fraction of each size class of dust in emission, $u_{10 \mathrm{~m}}$ is the horizontal wind speed at $10 \mathrm{~m}, u_{\mathrm{t}}$ is the threshold wind velocity below which dust emission does not occur and is a function of particle size, air density, and surface moisture. In this study, the source function $S$, shown in Fig. 1, is prescribed as in Ginoux et al. (2001). As described 

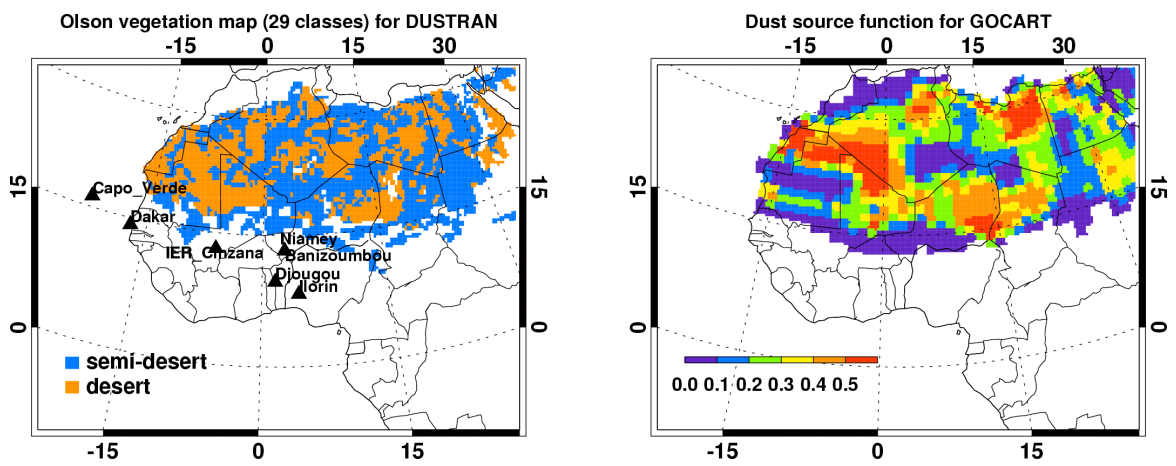

Fig. 1. Spatial distribution of desert and semi-desert masks determined by the Olson World Ecosystem database (29 classes) for the DUSTRAN scheme and the dust source function (Ginoux et al., 2001) for the GOCART scheme over North Africa. The black triangles represent the locations of the six AERONET sites. The Niamey airport, $60 \mathrm{~km}$ northwest from the Banizoumbou site, is also shown with the same triangle as Banizoumbou.

by Shaw et al. (2008), the DUSTRAN scheme calculates the dust emission flux $G$ as

$G=\alpha C u_{*}^{4}\left(1-\frac{f_{\mathrm{w}} u_{* \mathrm{t}}}{u_{*}}\right)$

where $C$ is an empirical proportionality constant, $\alpha$ is the vegetation mask accounting for vegetation type effect, $u *$ is the friction velocity, $u_{* t}$ is the threshold friction velocity (20 $\mathrm{cm} \mathrm{s}^{-1}$ following Shaw et al., 2008) below which dust emission does not occur, and $f_{\mathrm{w}}$ is the soil wetness factor accounting for soil moisture effect. In this study, the vegetation masks are determined by the Olson World Ecosystem database (Olson, 1992), and $\alpha$ is assigned to be 0.5 for semi-desert, 1.0 for desert, and 0 for others following Shaw et al. (2008) (Fig. 1). Although the values of the empirical proportionality constant $C$ were provided by both Ginoux et al. (2001) and Shaw et al. (2008), the values are highly tunable because they were estimated initially based on regional specific data. Therefore, in this study, we tune the $C$ values to make the model simulated mean AOD consistent with the AERONET measurements at the two sites, Banizoumbou and IER Cinzana, over the Sahel region. The tuned $\mathrm{C}$ values in different simulation cases are discussed in the following. Only dust particles with radius less than $10 \mu \mathrm{m}$ are emitted by the GOCART and DUSTRAN schemes in our simulations, because particles larger than $10 \mu \mathrm{m}$ radius generally have short atmospheric lifetimes due to gravitational settling (Tegen and Fung, 1994).

Originally, both the GOCART and DUSTRAN schemes model the emitted dust into several size bins. The GOCART scheme distributes the emitted dust into eight size bins $(0.1-0.18 \mu \mathrm{m}, 0.18-0.3 \mu \mathrm{m}, 0.3-0.6 \mu \mathrm{m}, 0.6-1.0 \mu \mathrm{m}, 1-$ $1.8 \mu \mathrm{m}, 1.8-3 \mu \mathrm{m}, 3-6 \mu \mathrm{m}$, and $6-10 \mu \mathrm{m}$ in radius), while the DUSTRAN scheme distributes the emitted dust into two size bins $(0.5-1 \mu \mathrm{m}$ and $1-10 \mu \mathrm{m}$ in radius). Neither scheme provides directly the log-normal size distribution parameters of emitted dust (i.e., the volume median diameter $\left(d_{\mathrm{pgv}}\right)$ and the standard deviation $\left(\sigma_{\mathrm{g}}\right)$ of the log-normal distribution and the mass fractions $\left(F_{\mathrm{m}}\right)$ among different modes) that are needed for the MADE/SORGAM aerosol model. Therefore, in this study, the two schemes are only used to calculate the total dust mass fluxes and the size distribution of emitted dust is estimated as discussed in following.

When estimating the size distributions of emitted dust, we estimate the log-normal size distribution for the MADE/SOGAM aerosol model first, and then integrate the mass following the log-normal size distribution into the eight size bins in the MOSAIC aerosol model, to make the size distributions of emitted dust consistent between the two aerosol models. For the log-normal size distribution, we assume that dust particles are emitted in accumulation and coarse modes. The $\sigma_{\mathrm{g}}$ of the two modes are obtained from the values (2.2 for accumulation mode and 1.73 for coarse mode) suggested by Osborne et al. (2008) for the DABEX measured dust over the dust source region and are constant during the simulation, while the volume mean diameters of aerosols in the two modes are updated from the predicted aerosol mass and number concentrations in each mode during the simulation. The first group of $d_{\mathrm{pgv}}$ and $F_{\mathrm{m}}$ of emitted dust in the two modes are estimated to best represent the original size distribution (in eight size bins) of emitted dust from the GOCART scheme. The $d_{\mathrm{pgv}}$ and $F_{\mathrm{m}}$ for the two modes are adjusted to minimize root mean square (RMS) of the difference between the two-mode log-normal size distribution and the GOCART original size distribution (in eight size bins). This way, we obtained the first modal size distribution (Modal1) with $15 \%$ of mass distributed in the accumulation mode $\left(d_{\mathrm{pgv}}=2.91 \mu \mathrm{m}\right.$ and $\left.\sigma_{\mathrm{g}}=2.20\right)$ and $85 \%$ of mass distributed in the coarse mode $\left(d_{\mathrm{pgv}}=6.91 \mu \mathrm{m}\right.$ and $\left.\sigma_{\mathrm{g}}=1.73\right)$ as shown in Fig. 2 . We then integrate the mass following the Modall size distribution into the eight size bins in the MOSAIC aerosol model to obtain the corresponding sectional size distribution (Sect. 1). 


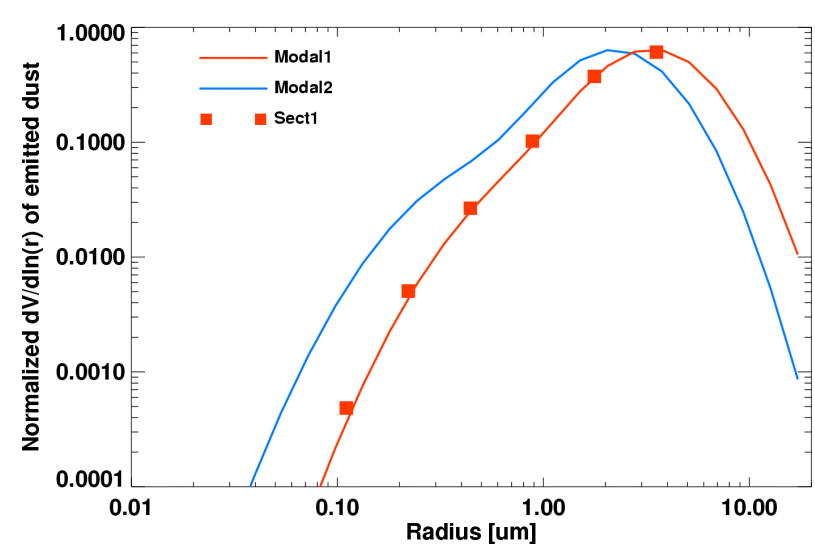

Fig. 2. Normalized volume size distributions of emitted dust from two cases for modal approach (Modal1 and Modal2) in MADE/SORGAM and one case for sectional approach (Sect1) in MOSAIC.

In order to investigate the modeling sensitivities of mineral dust and its radiative forcing to size distributions of emitted dust, we estimate another group of $d_{\mathrm{pgv}}$ and $F_{\mathrm{m}}$ of emitted dust for the modal size distribution in the MADE/SORGAM aerosol model. The second log-normal size distribution (Modal2) is obtained from the two-mode log-normal size distribution suggested by Osborne et al. (2008) for the DABEX measured dust over the dust source region (Fig. 2). In order to best fit the size distribution of measured dust during the DABEX, Osborne et al. (2008) provides two-mode lognormal distribution with $13 \%$ of mass into the accumulation mode $\left(d_{\mathrm{pgv}}=1.26 \mu \mathrm{m}\right.$ and $\left.\sigma_{\mathrm{g}}=2.20\right)$ and $87 \%$ of mass into the coarse mode $\left(d_{\mathrm{pgv}}=4.5 \mu \mathrm{m}\right.$ and $\left.\sigma_{\mathrm{g}}=1.73\right)$. The size distributions of Modal1, Modal2, and Sect1 are shown as normalized volume size distributions in Fig. 2, where the total volume of emitted dust is normalized to 1 . Modal 2 distributes more emitted dust, $\sim 15 \%$ of the total mass, into the submicron regime (radius $<1 \mu \mathrm{m}$ ), versus $\sim 6 \%$ in Modal1. The difference in size distributions of emitted dust will result in differences of not only the size distribution but also the spatial distribution and hence the radiative forcing of mineral dust (Sects. 4.2 and 5).

With two dust emission schemes (GOCART and DUSTRAN), two aerosol models (MADE/SORGAM and MOSAIC), and different size distributions of emitted dust (Modal1 and Modal2), we conducted four WRF-Chem simulations to investigate the modeling sensitivities of mineral dust and its radiative forcing to 1) dust emission schemes (Sect1-G versus Sect1-D); 2) size distributions of emitted dust (Modal1-G versus Modal2-G); and 3) aerosol size treatments (Sect1-G versus Modal1-G). The simulations are summarized in Table 1. The $C$ values in dust schemes are tuned differently for different cases. For the GOCART scheme, the $C$ value is tuned to $0.65 \mu \mathrm{g} \mathrm{s}^{2} \mathrm{~m}^{-5}$ based on Sect1-G results and is kept the same for Sect1-G and Modal1-G because they
Table 1. WRF-Chem simulations.

\begin{tabular}{llll}
\hline & \multicolumn{2}{c}{ MADE/SORGAM } & MOSAIC \\
\cline { 2 - 4 } & Modal1 & Modal2 & Sect1 \\
\hline GOCART & Modal1-G & Modal2-G & Sect1-G \\
DUSTRAN & - & - & Sect1-D \\
\hline
\end{tabular}

Modal1 and Modal2 represent the two modal size distributions of emitted dust in the MADE/SORGAM aerosol model. Sect1 represents the sectional size distribution of emitted dust in the MOSAIC aerosol model corresponding to the Modal1 modal size distribution.

have the same total amount and size distributions of emitted dust. The $C$ value in Modal2-G is tuned differently to $0.40 \mu \mathrm{g} \mathrm{s}^{2} \mathrm{~m}^{-5}$ to make Modal2-G simulated AOD similar to that from Modal1-G over the dust source region, because Modal2-G has a different size distribution of emitted dust, which can greatly affect the dust optical depth. For the DUSTRAN scheme, the $C$ value is tuned to $0.33 \times 10^{-14} \mathrm{~g} \mathrm{~cm}^{-6}$ $\mathrm{s}^{-3}$ based on Sect1-D results. The original $C$ values are 1.0 $\mu \mathrm{g} \mathrm{s}^{2} \mathrm{~m}^{-5}$ in Ginoux et al. (2001) and $1.0 \times 10^{-14} \mathrm{~g} \mathrm{~cm}^{-6} \mathrm{~s}^{-3}$ in Shaw et al. (2008).

\section{Measurements}

\subsection{DABEX aircraft in-situ measurements}

The Dust and Biomass-burning Experiment (DABEX) is a United Kingdom (UK) Met Office led field campaign involving the UK FAAM aircraft to investigate the properties of mineral dust and biomass burning aerosols over North Africa in the vicinity of Niamey, Niger from 13 January to 3 February in 2006 (referred to as the DABEX period hereafter). It coincided with the dry season special observing period (SOP-0) of the African Monsoon Multidisciplinary Analysis (AMMA) (Redelsperger et al., 2006). The flights of the FAAM aircraft were coordinated with ground observations and an ultra-light aircraft that were deployed as part of AMMA-SOP-0 (Haywood et al., 2008). In this study, the DABEX measured size distributions of mineral dust, aerosol optical depth, and aerosol extinction profiles are used for model evaluation. The aerosol extinction profiles were derived from a nephelometer, an instrument for measuring suspended particulates in a liquid or gas colloid, and a Particle Soot Absorption Photometer on the FAAM aircraft (Johnson et al., 2008a). The Angström exponent is used to partition the aerosol extinction profiles between mineral dust and biomass burning aerosols. The overall uncertainty of the extinction coefficient was estimated to be around $\pm 10 \%$ for biomass burning aerosols and $\pm 25 \%$ for mineral dust (Johnson et al., 2008a). A detailed description of the instruments and analysis of the physical and optical properties of mineral dust and aerosol extinction profiles during the DABEX can be found 
in Haywood et al. (2008), Johnson et al. (2008a, b), and Osborne et al. (2008).

During the DABEX, the size distributions of particles between 0.05 and $1.5 \mu \mathrm{m}$ in radius were measured by the Passive Cavity Aerosol Spectrometer Probe 100-X (PCASP) mounted externally under the aircraft wing. Particles larger than $1.5 \mu \mathrm{m}$ were measured using PCASP-X mounted inside the aircraft cabin that used a counter flow virtual impactor (CVI) inlet operating in a passive aerosol mode (Johnson et al., 2000; Osborne et al., 2008). The raw data from the instrumentation contains some noise and bin-to-bin fluctuations due to the difficulties of assigning counted particles to the correct size bin. The in-situ probes measure scattered signal and relate this to particle size through a set of assumptions and Mie theory. In some regions of the size spectrum there is not a unique relationship between scattered signal and particle size (multiple sizes can theoretically give the same signal amplitude due to the phenomena of optical resonance). Therefore, the fitted line was constructed of log-normals instead of the raw data to show size distributions of particles (Osborne et al., 2008). The log-normals naturally smooth over some of these instrumental features and are therefore more realistic of the real aerosol size distributions. The fitted line is used in the comparison with model results in this study.

\subsection{AERONET surface observation network}

The Aerosol Robotic Network (AERONET) (Holben et al., 1998) with $\sim 100$ identical globally distributed sun- and sky-scanning ground-based automated radiometers provides measurements of aerosol optical properties throughout the world (Dubovik and King, 2000; Dubovik et al., 2002). In this study, the AERONET measured aerosol optical depth (AOD) and single scattering albedo (SSA) at $675 \mathrm{~nm}$ and $440 \mathrm{~nm}$ from six sites over North Africa are used to derive the AOD at $550 \mathrm{~nm}$ (using the Angström exponent) and SSA at $600 \mathrm{~nm}$ (using linear interpolation) for comparison with model results and other retrievals. These six sites are Banizoumbou $\left(13^{\circ} \mathrm{N}, 2^{\circ} \mathrm{E}\right)$ and IER Cinzana $\left(13^{\circ} \mathrm{N}, 5^{\circ} \mathrm{W}\right)$ over the Sahel region, Djougou $\left(9^{\circ} \mathrm{N}, 1^{\circ} \mathrm{E}\right)$ and Ilorin $\left(8^{\circ} \mathrm{N}, 4^{\circ} \mathrm{E}\right)$ over the southern biomass burning region, Dakar $\left(14^{\circ} \mathrm{N}\right.$, $\left.16^{\circ} \mathrm{W}\right)$ at the coast, and Capo Verde $\left(16^{\circ} \mathrm{N}, 22^{\circ} \mathrm{W}\right)$ on a near-coast island. Each site is shown in Fig. 1 as a triangle. All of the retrievals of AOD and SSA selected in this study are quality level 2, and the uncertainty of AOD measurements is about \pm 0.01 (Holben et al., 2001).

\subsection{ARM MPL lidar}

The US Department of Energy's Atmospheric Radiation Measurements (ARM) Program Mobile Facility (AMF) was fully equipped with comprehensive instrumentation and was located at the Niamey airport, which is $\sim 60 \mathrm{~km}$ northwest from the AEROENT Banizoumbou site, from January through December in 2006 (Miller and Slingo, 2007). The aerosol extinction and broadband SW heating profiles and column-averaged SSA derived from the AMF are used in this study. Aerosol extinction profiles at $523 \mathrm{~nm}$ are calculated using a micropulse lidar (MPL) and the column AOD is retrieved from the MultiFilter Rotating Shadowband Radiometer (MFRSR). The total uncertainty in the derived extinction profiles is estimated to be $0.093 \mathrm{~km}^{-1}$ in the dust layers and slightly less in the biomass burning layers (McFarlane et al., 2009). The column-averaged SSA and asymmetry parameter at five wavelengths were retrieved from MFRSR observations using the retrieval technique described by Kassianov et al. (2007). Using the derived extinction profiles and aerosol optical properties, along with observations of temperature and water vapor from the AMF measurements, broadband SW heating profiles were calculated at 15 -min intervals using a 1-D radiative transfer model. The details of the retrievals of the aerosol extinction and column-averaged SSA and the calculations of the SW heating profiles can be found in McFarlane et al. (2009).

\subsection{MODIS}

The Moderate Resolution Imaging Spectroradiometer (MODIS) instruments on board the NASA Terra and Aqua platforms are uniquely designed with wide spectral range, high spatial resolution, and near daily global coverage to observe and monitor the Earth changes including tropospheric aerosols (Kaufman et al., 1997). The standard MODIS aerosol product does not retrieve aerosol information over bright surfaces (e.g., Sahara desert) due to a strong surface spectral contribution in the visible range (Kaufman et al., 1997). However, recently, a new algorithm, called "Deep Blue algorithm" (Hsu et al., 2006), has been integrated with existing MODIS algorithm to retrieve AOD even over bright surfaces. Therefore, in this study, the retrieved "deep blue" AOD from MODIS (Collection 5) (only available over land and from the MODIS on Aqua so far) (Levy et al., 2007; Remer et al., 2005) is used over the land, while the standard retrieved AOD is used over the ocean. The MODIS on board the Aqua platform passes over the equator at $\sim 13: 30 \mathrm{LT}$ during the daytime (Kaufman et al., 1997). When comparing model simulated AOD with MODIS retrievals, model results are sampled in the same overpass time as Aqua.

\subsection{MISR}

The Multi-angle Imaging SpectroRadiometer (MISR) instrument on board the NASA Terra platform has been producing AOD globally since February 2000. MISR observes continuously at nine distinct zenith angles, ranging from $70^{\circ}$ afterward to $70^{\circ}$ forward, and in four narrow spectral bands centered at 446, 558, 672, and $866 \mathrm{~nm}$. MISR's unique blend of directional and spectral data allows aerosol retrieval algorithms to be used not depending on explicit radiometric 


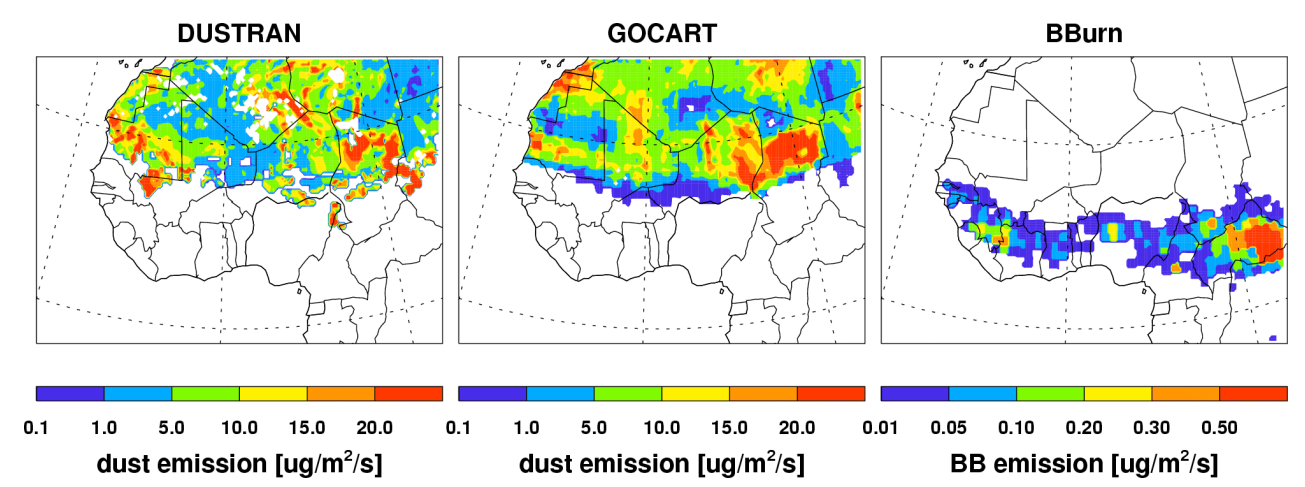

Fig. 3. Dust emissions from the DUSTRAN and GOCART dust schemes and biomass burning emissions (OC+BC) from the GFEDv2 inventory for the simulation period (6 January-5 February 2006) over North Africa. "BBurn" represents biomass burning.

surface properties. As such, MISR can retrieve aerosol properties even over the highly reflective surfaces like deserts (Diner et al, 1998; Martonchik et al., 2004). The MISR on board the Terra platform passes over the equator at $\sim 10: 45$ LT during the daytime (Diner et al., 2001). When comparing model simulated AOD with MISR retrievals, model results are sampled in the same overpass time as Terra.

\section{Modeling the dust distribution}

\subsection{Dust emissions}

Figure 3 shows the spatial distributions of dust emission fluxes from the Sect1-G and Sect1-D simulations with the GOCART and DUSTRAN schemes respectively averaged during the simulation period over North Africa. Both schemes simulate similar amount $(\sim 200 \mathrm{Tg})$ of total dust emissions over North Africa during the simulation period after the appropriate parameter (the $C$ value) is adjusted as described above. The spatial distributions of dust emissions are mainly dominated by the spatial distributions of the dust source function in the GOCART scheme and the desert and semi-desert masks over North Africa in the DUSTRAN scheme (Fig. 1). Both schemes simulate consistent spatial distribution showing that dust emissions mainly occur over the Sahara desert regions $\left(15^{\circ} \mathrm{N}-35^{\circ} \mathrm{N}\right)$ of northern North Africa with a large amount of dust emissions over northern Niger and Chad, but the DUSTRAN scheme simulates more dust emissions near the west coast of North Africa. The temporal evolutions of the total dust emissions over North Africa from the two schemes are well correlated with a correlation coefficient of 0.96 (Fig. 4), indicating the dominant influence of the WRF simulated $10-\mathrm{m}$ wind speed $\left(u_{10 \mathrm{~m}}\right)$ and friction velocity $\left(u_{*}\right)$ on the temporal evolution of dust emissions in the two schemes. Both schemes simulate three dust storms (around 1, 19, and 30 January) with a maximum daily dust emission of $\sim 12 \mathrm{Tg}$ during the simulation period, which significantly contribute to the simulated AOD near the dust source regions (Sect. 5). Modal1-G simulates the same dust emissions as Sect1-G, while Modal2-G simulates similar spatial and temporal distributions of emitted dust but $\sim 40 \%$ less of total emission amount (124 Tg) over North Africa during the simulation period than Sect1-G because of its smaller $C$ value to match the simulated AOD by Modal1-G. Biomass burning emissions (BBurn) of BC and OC (organic carbon) are also shown in Fig. 2 for comparison with dust emissions. Biomass burning emission is the dominant aerosol source over southern North Africa.

\subsection{Dust size and spatial distribution}

Figure 5 shows the normalized cross-sectional area size distributions of the WRF-Chem simulated dust particles in different cases in the daytime (09:00-16:00 UTC) during the simulation period over northeast Niamey $\left(17.5^{\circ}-18.5^{\circ} \mathrm{N}\right.$, $5^{\circ}-7^{\circ} \mathrm{W}$ ) at $500-1000 \mathrm{~m}$ above the ground level (a.g.l.), where the DABEX aircraft sampled the "pure" dust (Osborne et al., 2008). The cross-sectional areas of dust particles are calculated as $\pi r^{2}$, where $r$ is the radius of the particle. The total "normalized" cross-sectional area of dust particles is equal to 1 . Cross-sectional area size distribution is shown instead of volume size distribution because it can better represent the optical properties (i.e., extinction crosssection) of particles. The log-normal fit suggested by Osborne et al. (2008) to best represent the size distribution of the DABEX aircraft measured "pure" dust is also shown. Aerosol size distributions are also retrieved from AERONET at the Banizoumbou site; however Osborne et al. (2008) showed that the AEROENT retrieved aerosol size distributions have a large bias versus aircraft measurements over the vicinity of Niamey. We obtained the same comparison as Osborne et al. (2008) and hence do not show the AERONET retrievals in this figure.

Modal1-G and Sect1-G simulate different size distributions of dust particles, although they have the same size distributions of emitted dust. Modal1-G overestimates the dust 


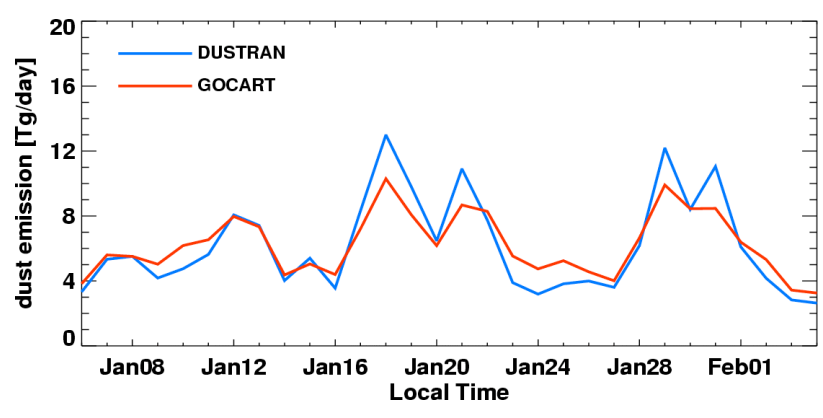

Fig. 4. Daily total dust emissions from the DUSTRAN and GOCART schemes in Sect1-G and Sect1-D cases over North Africa for the simulation period.

in the submicron size range and underestimates the dust in the super-micron size range compared to the aircraft measurements, while Sect1-G well captures the features in the aircraft measurements. The difference in size distributions between Modal1-G and Sect1-G mainly results from their different aerosol size treatments: modal versus sectional approaches. The poorer performance of the modal approach, in terms of simulating size distributions of dust, may result from its limited number of modes (only two, accumulation and coarse), and the use of constant geometric standard deviation $\sigma_{\mathrm{g}}$. In our model, although the fundamental processes of aerosol dry deposition are parameterized in the same way for both modal and sectional approaches, the prescribed $\sigma_{\mathrm{g}}$ for each mode could cause bias in calculating the aerosol dry deposition rate for that mode. Our sensitivity tests show that the dry deposition rate is sensitive to the prescribed $\sigma_{\mathrm{g}}$ for each mode in the model. The modal approach retains more fine dust but less coarse dust versus the sectional approach with current values of $\sigma_{\mathrm{g}}$ (i.e., $\sigma_{\mathrm{g}}=2.2$ for accumulation mode and $\sigma_{\mathrm{g}}=1.75$ for coarse mode), because it simulates a smaller dry deposition rate for fine particles but a larger dry deposition rate for coarse particles, compared to the sectional approach. Several sensitivity tests with different $\sigma_{\mathrm{g}}\left(\sigma_{\mathrm{g}}=1.6-\right.$ 2.5) for accumulation and coarse modes show that the adjustments of $\sigma_{\mathrm{g}}$ could make the size distribution from modal approach better or worse versus measurements. The quantitative analysis of the bias from the prescribed $\sigma_{\mathrm{g}}$ of modal approach in simulating aerosol size distribution will be in the scope of our future study. The Modal2-G simulated size distribution shifts towards smaller sizes and has a larger bias than that of Modal1-G compared to aircraft measurements. The difference of dust size distributions between Modal1-G and Modal2-G results from their use of different size distributions of emitted dust.

Different size-resolved dust emissions and aerosol size treatments result in different dust concentrations. Figure 6 shows the mean spatial distribution of the WRF-Chem simulated lower atmospheric ( $<1 \mathrm{~km}$ a.g.1.) dust mass concentrations of dust particles with radius less than $5 \mu \mathrm{m}$

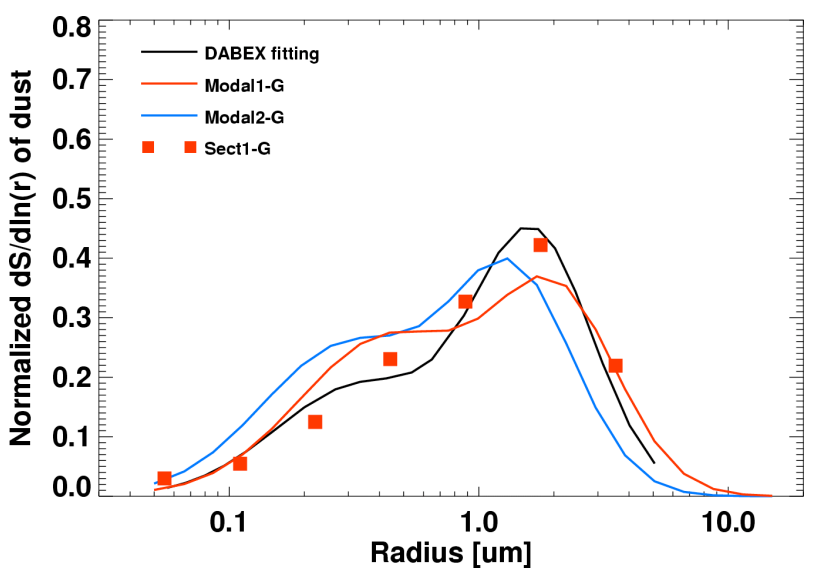

Fig. 5. Normalized cross-sectional area size distributions of mineral dust from the fitting of DABEX aircraft measurements and the WRF-Chem simulations in three cases (Modal1-G, Modal2-G, and Sect1-G). Cross-sectional areas of particles are calculated as $\pi r^{2}$, where $r$ is the radius of a particle.

$(r<5 \mu \mathrm{m})$ in the daytime (09:00-16:00 UTC) from different cases (Modal1-G, Modal2-G, Sect1-G and Sect1-D) over North Africa during the simulation period. The mass concentrations are shown not only for dust particles in the whole size range $(r<5 \mu \mathrm{m})$ but also for fine particles $(r<1.25 \mu \mathrm{m})$ and coarse particles $(1.25<r<5 \mu \mathrm{m})$ separately. The spatial distributions of dust concentrations are generally consistent with the patterns of dust emissions. With similar dust emissions, Sect1-G and Sect1-D simulate close domain-averaged dust concentrations of 197 and $202 \mu \mathrm{g} / \mathrm{m}^{3}$ for particles in the whole size range, 44 and $43 \mu \mathrm{g} / \mathrm{m}^{3}$ for fine particles, and 153 and $159 \mu \mathrm{g} / \mathrm{m}^{3}$ for coarse particles, respectively. Although Modal1-G with different aerosol size treatment produces different dust size distributions from Sect1-G, it simulates similar dust mass concentrations of particles in the whole size range to Sect1-G with a domain averaged concentration of $198 \mu \mathrm{g} / \mathrm{m}^{3}$, which may indicate that the total dust burden is mainly controlled by the emission and dry deposition processes of dust in the model during the simulation period (dry season with small wet deposition effect) near the dust source region. However, Modal1-G simulates 25\% higher mass concentrations $\left(56 \mu \mathrm{g} / \mathrm{m}^{3}\right)$ for fine dust particles and $8 \%$ lower mass concentrations $\left(142 \mu \mathrm{g} / \mathrm{m}^{3}\right)$ for coarse dust particles than Sect1-G, reflecting its different dust size distributions from Sect1-G. Compared to Modal1-G, Modal2-G simulates $14 \%$ lower domain averaged concentrations $\left(170 \mu \mathrm{g} / \mathrm{m}^{3}\right)$ for dust particles in the whole size range, $15 \%$ higher $\left(66 \mu \mathrm{g} / \mathrm{m}^{3}\right)$ for fine dust particles, and $27 \%$ lower $\left(104 \mu \mathrm{g} / \mathrm{m}^{3}\right)$ for coarse dust particles due to its emissions of less total dust mass but more dust particles with smaller sizes. 

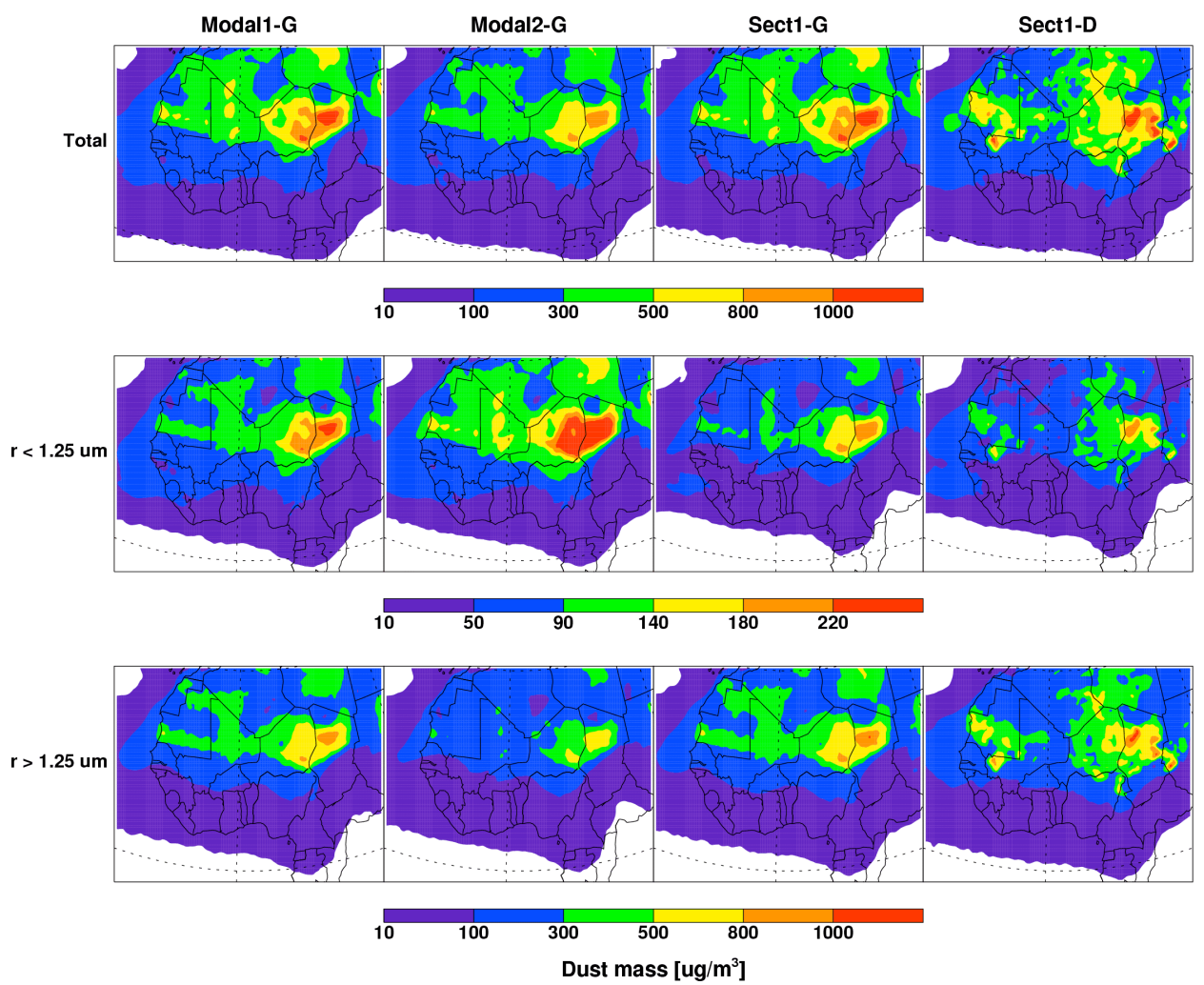

Fig. 6. Daytime (09:00-16:00 UTC) dust mass concentrations below $1 \mathrm{~km}$ a.g.l. for the simulation period over North Africa from the WRFChem simulations in four cases: Modal1-G, Modal2-G, Sect1-G, and Sect1-D. The mass concentrations are shown for dust particles in the whole size range $(r<5 \mu \mathrm{m})$, fine dust particles $(r<1.25 \mu \mathrm{m})$, and coarse dust particles $(1.25 \mu \mathrm{m}<r<5 \mu \mathrm{m})$, respectively.

\section{Modeling the shortwave radiative forcing of mineral dust}

\subsection{Impact on Aerosol Optical Depth (AOD)}

Mineral dust significantly contributes to the AOD over North Africa. Figure 7 shows the mean spatial distribution of AOD at $550 \mathrm{~nm}$ from MISR and MODIS satellite retrievals and the corresponding WRF-Chem simulations with and without dust emissions during the simulation period over North Africa. Model results are sampled in the same over-path with satellites. MISR and MODIS show consistent spatial patterns of the AOD with a correlation coefficient of 0.72. Both of them show the highest AOD over southern North Africa resulting from the combination of mineral dust transported from the north and the biomass burning aerosols. The domain averaged AOD observed by the two satellites is similar: 0.32 from MISR versus 0.31 from MODIS. Among the WRF-Chem simulations in different cases, Modal1-G, Modal2-G, Sect1-G and Sect1-D simulate similar results with domain averaged AOD of 0.37, 0.37, 0.36, and 0.36 respectively because of the tuning of dust emissions, 10 $15 \%$ higher than satellite retrievals. The spatial distributions of AOD from the four simulations are consistent with those from satellite retrievals with correlation coefficients $(R)$ of $\sim 0.70$, particularly over the Sahara desert, indicating that the dust source regions are well represented by the dust source function in the GOCART scheme and the Olson vegetation map in the DUSTRAN scheme over North Africa. The WRF-Chem simulation without dust emissions significantly underestimates the domain averaged AOD with a value of 0.20 , particularly over the Sahara desert.

Figure 8 shows the hourly column AOD at $550 \mathrm{~nm}$ from WRF-Chem simulations with and without dust emissions, in comparison with the AERONET measurements at six sites over North Africa, the MISR and MODIS retrievals, and the DABEX aircraft measurements (only available at the Banizoumbou site) during the simulation period. From the AERONET measurements, the Djougou and Ilorin sites over the biomass burning area have the highest period averaged AOD of 0.72 and 0.94 respectively with the peaks up to 1.7, compared to 0.41 and 0.36 at the Banizoumbou and IER Cinzana sites over the Sahel region respectively, 0.35 at the Dakar site at the coast, and 0.20 at the Capo Verde site on a near-coast island. Satellite retrievals generally correlate well with the AEROENT measurements, although they have lower values than the AERONET measurements particularly at the Djougou and Ilorin sites. Very few retrievals 

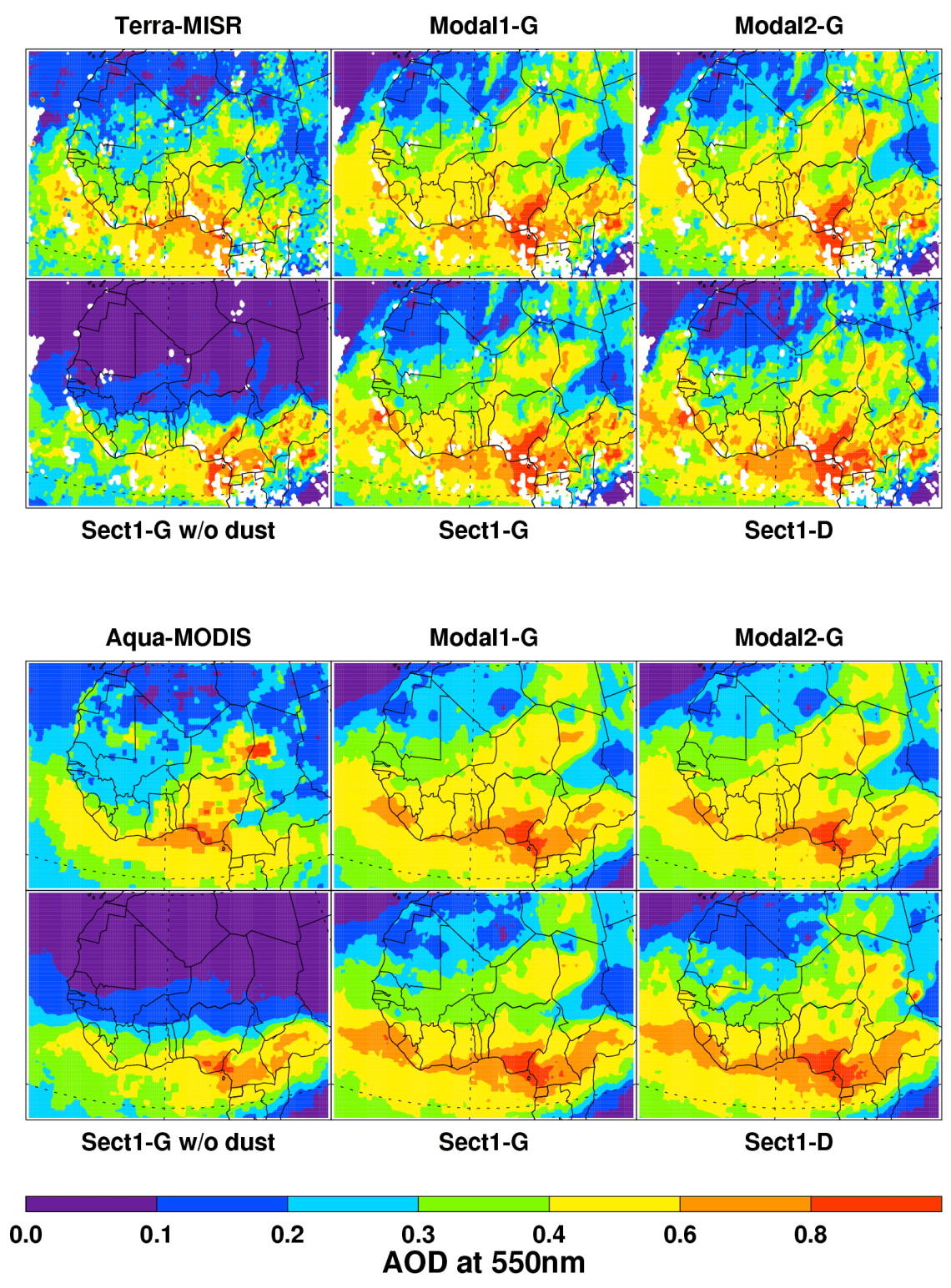

Fig. 7. Averaged AOD at $550 \mathrm{~nm}$ over North Africa during the simulation period from the retrievals of MISR on Terra and MODIS on Aqua and the corresponding simulations of WRF-Chem in different cases. The MODIS retrievals are the combination of the standard (over ocean) and "Deep Blue" (over land) products. Model results are sampled at the time and locations of the MISR and MODIS retrievals respectively. The blank area in plots means no data available.

are available from MISR due to its narrower swath width. At Banizoumbou, the DABEX aircraft measured AOD are consistent with the AERONET measurements with a period average of 0.44 .

At Banizoumbou and IER Cinzana, Sect1-G and Sect1D simulate similar results and generally reproduce the AERONET measurements with period averaged AOD of 0.40 and 0.42 at Banizoumbou and 0.37 and 0.36 at IER Cinzana respectively (the model average is calculated only from time samples when AERONET measurements are available, the same hereafter), because the dust emissions (the $C$ value) were tuned through comparing the Sect1-G and Sect1-D simulated results and AERONENT retrievals at these two sites. Modal1-G simulates 11\% higher AOD of 0.44 and 0.41 than Sect1-G at these two sites due to its simulation of more dust particles in smaller sizes. Modal2-G simulates similar AOD as Modal1-G because of the tuning of dust emissions. All four cases successfully capture two observed dust storm episodes (18-22 and 26-31 January). The simulation without dust emissions significantly underestimates the AOD at both sites. At Djougou and Ilorin, all four cases simulate period averaged AOD of $0.47-0.50$ at Djougou and 0.65-0.69 

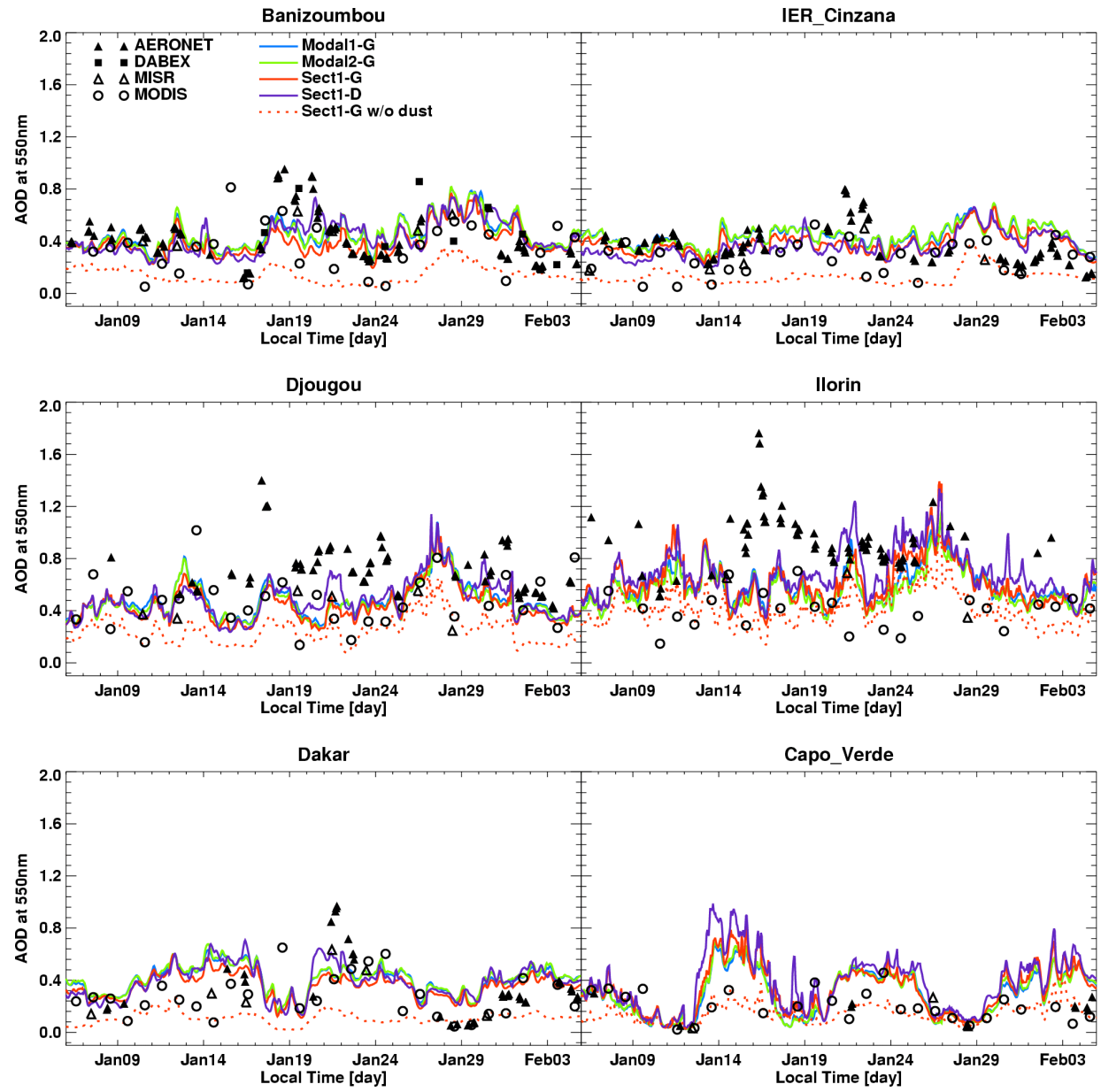

Fig. 8. Hourly AOD at $550 \mathrm{~nm}$ from the AERONET measurements, MISR and MODIS retrievals, DABEX aircraft measurements (Banizoumbou only) and the corresponding WRF-Chem simulations in different cases during the simulation period at the six AERONET sites over North Africa.

at Ilorin respectively, which are higher than satellite retrievals but lower than AERONET measurements. All the four cases capture the lower values of the AERONET measured AOD $(<1.0)$ at the two sites, but significantly underestimate the higher values (e.g., up to 1.5 at Djougou and up to 1.7 at Ilorin around 16 January). These occasional high AOD measured at these two sites are likely due to local biomass burning, which is difficult to be simulated by the model using the GFEDv2 biomass burning emission inventory with 8-day temporal resolution. At Dakar and Capo Verde, the MODIS retrievals are generally consistent with the AEROENT measurements, although there are very few measurements available from AERONET at these two sites. The four cases simulate period averaged AOD of 0.34-0.40 at Dakar and 0.350.41 at Capo Verde respectively, and successfully capture the AERONET and satellite observed outflow events during 1416 and 22-26 January and 31 January-3 February, but generally overestimate the magnitude of the outflows, particularly for the first event at Capo Verde. Sect1-D simulates the highest averaged AOD at the two sites among these four cases because the DUSTRAN dust scheme simulates more dust emissions near the west coast of North Africa. The simulation without dust emissions does not show the dust outflow events. The model overestimation of the dust outflow may result from the bias of WRF in simulating the wind fields during these periods, when WRF simulates stronger low-level $(925 \mathrm{hPa})$ westerly wind speed than that from the NCEP reanalysis data over the band of $15^{\circ} \mathrm{N}-20^{\circ} \mathrm{N}$ (figure not shown). The comparison of the period averaged AOD among various measurements and model simulations is summarized in Table 2. MISR is not shown due to its poor temporal coverage. The model averaged AOD is sampled at the time of the AERONET measurements, while the MODIS AOD is an average of all the data because MODIS does not always have data available at the time of the AERONET measurements. 
Table 2. AOD at $550 \mathrm{~nm}$ from various measurements and WRF-Chem simulations.

\begin{tabular}{lrrrrrrr}
\hline & AERONET & MODIS & Modal1-G & Modal2-G & Sect1-G & Sect1-D & w/o Dust \\
\hline Banizoumbou & 0.41 & 0.35 & 0.44 & 0.43 & 0.40 & 0.42 & 0.12 \\
IER Cinzana & 0.36 & 0.26 & 0.41 & 0.40 & 0.37 & 0.36 & 0.12 \\
Djougou & 0.72 & 0.47 & 0.50 & 0.49 & 0.47 & 0.49 & 0.22 \\
Ilorin & 0.94 & 0.40 & 0.65 & 0.66 & 0.65 & 0.68 & 0.37 \\
Dakar & 0.35 & 0.27 & 0.38 & 0.38 & 0.34 & 0.39 & 0.13 \\
Capo verde & 0.20 & 0.20 & 0.37 & 0.37 & 0.35 & 0.40 & 0.15 \\
\hline
\end{tabular}

"w/o Dust" represents the WRF-Chem simulation without dust emissions.

\subsection{Impact on aerosol extinction profile}

The vertical profiles of WRF-Chem simulated dust are evaluated through the comparison of the aerosol extinction coefficients from measurements and model simulations. Figure 9a shows the mean aerosol extinction (at $550 \mathrm{~nm}$ ) profiles (from surface to $5 \mathrm{~km}$ ) from the DABEX aircraft and AMF lidar retrievals and the corresponding WRF-Chem simulations during the DABEX period. The aerosol extinction from mineral dust and biomass burning aerosol components is also shown in Fig. 9b for both the DABEX measurements and model simulations. The DABEX profile shown here is the average of twenty profiles measured during eleven days within a mean distance of less than $100 \mathrm{~km}$ from the Niamey airport. The model average is sampled at the time and location of the DABEX aircraft measurements, while the AMF profile is the average of all available profiles retrieved at 08:0011:30 UTC in 19 days from 13 January to 3 February following Johnson et al. (2008a). The DABEX and AMF retrievals show generally consistent profiles with peak aerosol extinction at $\sim 0.20$ within $1 \mathrm{~km}$ from the surface. The aerosol extinction coefficient decreases with altitude. The difference between aircraft and AMF measurements may be due to sampling difference. A more detailed inter-comparison of the DABEX aircraft and AMF retrieved extinction profiles was presented in Johnson et al. (2008a).

Sect1-G with dust emissions successfully reproduces the vertical profiles of the measurements below $2 \mathrm{~km}$ with a similar peak value of aerosol extinction coefficient at $\sim 0.20$ below $1 \mathrm{~km}$. Above $2 \mathrm{~km}$, Sect1-G underestimates the aerosol extinction coefficients. When partitioning the aerosol extinction profile between the dust and biomass burning aerosol components, we find this underestimation results from the underestimation of biomass burning aerosols (Fig. 9b). The Sect1-G simulated dust component of aerosol extinction is consistent with the aircraft measurement, but its biomass burning aerosol component is $\sim 50 \%$ lower than the measurements above $1 \mathrm{~km}$. Mineral dust is the main component contributing to the aerosol extinction from the surface to $2 \mathrm{~km}$. A sensitivity simulation with doubling of biomass burning emissions (Sect1-G BBx2 case in Fig. 9a) shows a better result, almost reproducing the measured extinction profile

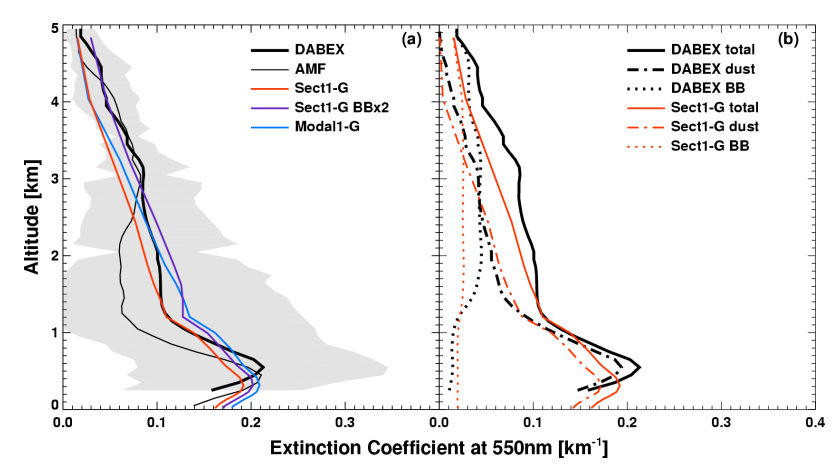

Fig. 9. (a) Aerosol extinction (at $550 \mathrm{~nm}$ ) profiles from the DABEX aircraft measurements, AMF lidar retrievals, and the WRF-Chem simulations in different cases for the DABEX period in the vicinity of Niamey. The gray area represents the standard deviation of the DABEX measurements; (b) aerosol extinction profiles from the DABEX measurements and Sect1-G simulations and their dust and biomass burning (BB) aerosol components.

above $2 \mathrm{~km}$. The Sect1-D simulated result is similar to Sect1$\mathrm{G}$ and hence is not shown. Modal1-G simulates 12\% larger aerosol extinction coefficient than Sect1-G and the difference mainly occurs below $2 \mathrm{~km}$. Modal2-G simulates similar results as Modal1-G (not shown).

\subsection{Impact on SW radiative heating profile}

Mineral dust not only scatters but also absorbs solar radiation, and thus can affect the SW heating profiles. The WRFChem model is also used to calculate the SW dust heating rate in this study. The real part of the refractive index of mineral dust $\left(n_{\mathrm{r}}\right)$ is relatively well defined and set to 1.53 in this study. However, estimates of the imaginary part $\left(n_{\mathrm{i}}\right)$ still have large variations with a range from $0.0004 \mathrm{i}$ to $0.006 \mathrm{i}$ at wavelengths around $550 \mathrm{~nm}$ suggested by previous studies (e.g., Patterson et al., 1977; Dubovik et al., 2002; Haywood et al., 2003; Kandler et al., 2007; Osborne et al., 2008; Petzold et al., 2009; Otto et al., 2009). A value of 0.003i in the middle of the range is used in the standard simulations discussed above. Figure 10 shows the hourly column-mean SSA at $600 \mathrm{~nm}$ from the AERONET retrievals at Banizoumbou, 
AMF retrievals at the Niamey airport, and the corresponding WRF-Chem simulations at Banizoumbou during the simulation period. The model simulated column-mean SSA is weighted by the AOD at each model layer. The AERONET retrievals of an average of 0.86 are lower than the AMF retrievals of 0.92 , particularly during 6-10 January. Osborne et al. (2008) found that the AERONET retrieved SSA at quality level 2 is systematically lower than that at quality level 1 for unknown reason, and is also lower than the average aircraft measurements of 0.91 over the vicinity of Niamey.

The Sect1-G simulated SSA values are between the AEROENT and AMF retrievals with a period average of 0.90 . Since the $n_{\mathrm{i}}$ of mineral dust is very uncertain, the variation of Sect1-G simulated SSA due to the uncertainty of $n_{\mathrm{i}}(0.0004 \mathrm{i}-0.006 \mathrm{i})$ is shown as the gray area in Fig. 10 . The upper and lower bounds of the gray area are calculated with the $n_{\mathrm{i}}$ equal to $0.0004 \mathrm{i}$ and $0.006 \mathrm{i}$ in the Sect1-G simulations respectively. It shows that the averaged SSA can range from 0.86 to 0.94 . The result from the Sect1-G sensitivity simulation with doubling of biomass burning emissions is also shown. The calculated column-mean SSA (0.89) from the sensitivity simulation is smaller than the standard Sect1-G simulation. Sect1-D simulates a similar result as Sect1-G (not shown). Modal1-G simulates a higher average value of 0.91 as compared to Sect1-G. Although the dust size distribution in Modal2-G shifts to smaller size as compared to Modal1-G, Modal2-G simulates similar SSA values as Modal1-G (not shown). The difference of SSA between Modal1-G and Sect1-G results from their difference in both size distribution and refractive index of aerosols. More smaller dust particles in Modal1-G changes not only the size distribution of aerosols but also the ratio of mass concentrations between dust and other aerosols (especially for BC) and hence the refractive index of aerosols which is calculated by volume averaging for aerosol species in WRF-Chem. In general, aerosols with smaller size are less absorbing. However, the difference of aerosol size distributions between Modal1$\mathrm{G}$ and Modal2-G is not significant enough to affect the SSA calculation. In order to investigate the SSA dependence solely on dust size distributions, we also conducted sensitivity simulations in which the AOD and refractive index of internal mixed aerosols are set to be the same in Modal1-G, Modal2-G, and Sect1-G cases. The same results are found (i.e., SSA in Modal1-G is similar to that in Modal2-G but higher than that in Sect1-G). It's also noteworthy that both of the retrievals from AERONET and AMF show large variations of SSA with time, while the model simulates less temporal variations of SSA. This may result from the missing local biomass burning sources in the model.

Figure 11a shows the mean SW aerosol and dust heating profiles at 08:00-12:00 UTC from the WRF-Chem simulations in Sect1-G and Modal1-G cases from the surface to $5 \mathrm{~km}$ at the Niamey airport during the DABEX period. The Sect1-D and Modal2-G simulated results are similar to Sect1-G and Modal1-G respectively and hence are not

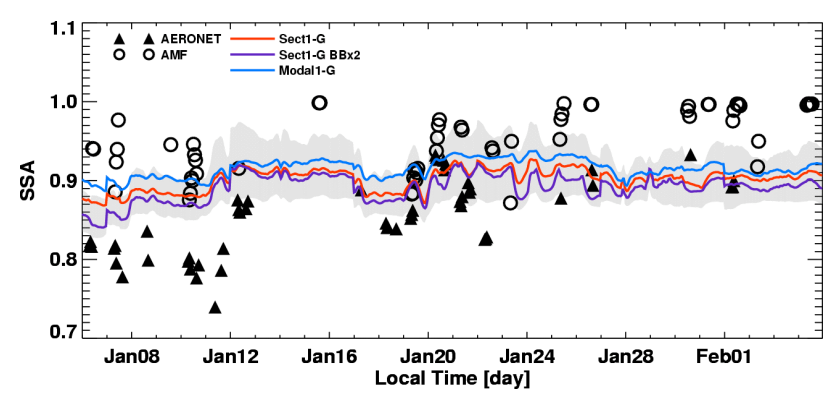

Fig. 10. Hourly SSA at $600 \mathrm{~nm}$ during the simulation period from the AERONET and AMF retrievals and the WRF-Chem simulations in different cases in the vicinity of Niamey. The gray area represents the variation of Sect1-G simulated SSA due to the uncertainty of $n_{\mathrm{i}}$ (imaginary part of refractive index) of mineral dust.

shown. Sect1-G simulates the SW dust heating with a maximum rate of $\sim 0.8 \mathrm{~K} /$ day at $0.5 \mathrm{~km}$ at the Niamey airport and a decreasing trend with altitude. On domain average, dust heats the lower atmosphere with an average rate of $\sim 0.5 \mathrm{~K} /$ day. The variation of the Sect $1-\mathrm{G}$ simulated SW dust heating rate due to the uncertainty of $n_{\mathrm{i}}$ of dust $(0.0004 \mathrm{i}-$ $0.006 \mathrm{i}$ ) is shown as the grey area. The change of $n_{\mathrm{i}}$ can significantly modulate the SW dust heating below $4 \mathrm{~km}$ with a maximum variation of $\pm 0.5 \mathrm{~K} /$ day below $1 \mathrm{~km}$. Modal1$\mathrm{G}$ simulates lower (up to $13 \%$ below $1 \mathrm{~km}$ ) SW dust heating rates than Sect1-G throughout the profile, reflecting its smaller dust particles that are less absorbing. The simulated SW aerosol heating profiles generally follow the SW dust heating profiles but with higher rates because they include biomass burning aerosols that heat the atmosphere with a rate up to $0.15 \mathrm{~K} /$ day below $1 \mathrm{~km}$ and $0.4 \mathrm{~K} /$ day above. The difference of simulated SW aerosol heating profiles between the two cases mainly results from their difference in simulating SW dust heating profiles.

Figure $11 \mathrm{~b}$ shows the mean $\mathrm{SW}$ aerosol heating profiles from the WRF-Chem simulations in the Sect1-G case and the calculation based on the AMF retrievals at the Niamey airport. The AMF profile is the average of all available profiles calculated at 08:00-12:00 UTC in 19 days from 13 January to 3 February to be consistent with its extinction profile shown in Fig. 9a. The model average is calculated only from time samples when the AMF calculations are available. The AMF profile shows two $\mathrm{SW}$ aerosol heating peaks of $1.5 \mathrm{~K} /$ day and $1.0 \mathrm{~K} /$ day at 0.5 and $3 \mathrm{~km}$ respectively. Below $2 \mathrm{~km}$, Sect $1-\mathrm{G}$ simulates a similar shape of the heating profile with a SW aerosol heating peak of $1.0 \mathrm{~K} /$ day at $0.5 \mathrm{~km}$. However, the Sect1-G standard simulation underestimates the AMF calculated SW aerosol heating rate below $1 \mathrm{~km}$ and above $2 \mathrm{~km}$. The model underestimation below $1 \mathrm{~km}$ partly results from its lower aerosol extinction coefficient (Fig. 9a). The AMF retrievals also have a larger bias below $1 \mathrm{~km}$ (McFarlane et al., 2009). Above $2 \mathrm{~km}$, the dust component of aerosol extinction (Fig. 9a) and the possible range of SW dust heating 


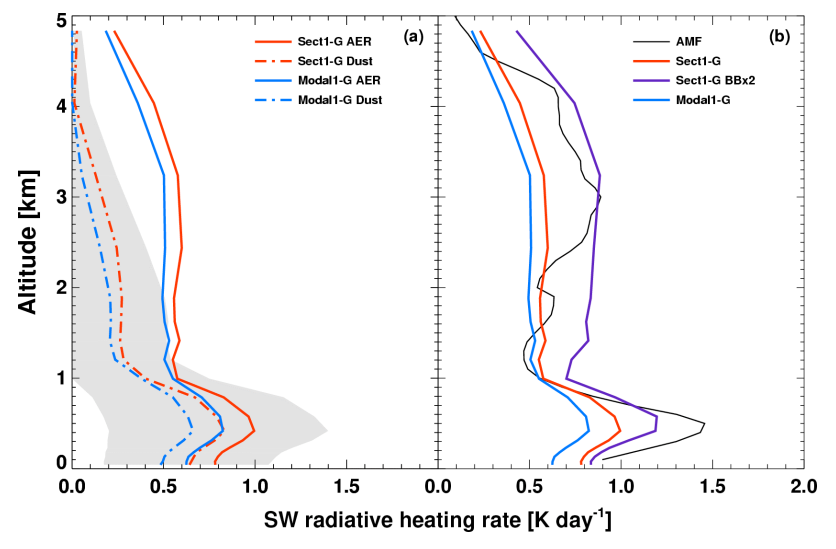

Fig. 11. (a) SW aerosol (solid line) and dust (dot dash line) heating profiles from the WRF-Chem simulations in different cases at 08:00-12:00 UTC for the DABEX period at the Niamey airport. The gray area represents the variation of Sect1-G simulated SW dust heating rate due to the uncertainty of $n_{\mathrm{i}}$ (imaginary part of refractive index) of mineral dust; (b) SW aerosol heating profiles from the calculations based on the AMF retrievals and the WRF-Chem simulations in different cases at 08:00-12:00 UTC for the DABEX period at the Niamey airport.

rate due to the uncertainty of $n_{\mathrm{i}}$ of dust (Fig. 11a) indicate that this underestimation is likely due to the biomass burning rather than dust aerosol component. Result from the sensitivity simulation of Sect1-G with doubling of biomass burning emissions shows that increasing biomass burning aerosols results in up to $65 \%$ increase of the SW aerosol heating rates above $2 \mathrm{~km}$ and thus better comparison with the AMF calculations. It may reflect the uncertainty of the GFEDv2 inventory in estimating the total amount and spatial distribution of biomass burning aerosols over North Africa and the bias of biomass burning aerosol injection heights used in the model. Further investigation of these issues is interesting but beyond the scope of this work.

\subsection{Impact on downwelling SW radiation}

The scattering and absorbing effect of mineral dust on SW radiation can significantly reduce the downwelling SW radiation at the surface. Figure 12 shows the spatial distribution of the clear-sky surface SW radiative forcing of dust at 12:00 UTC calculated from the Sect1-G simulations with and without dust emissions for the simulation period over North Africa. Sect1-G simulates significant surface SW radiative forcing of dust with a domain averaged value of $-22 \mathrm{~W} \mathrm{~m}^{-2}$ and a maximum of $-58 \mathrm{~W} \mathrm{~m}^{-2}$ over northern Niamey and Chad at 12:00 UTC, consistent with the patterns of the simulated dust concentrations and AOD. Over the Sahel region (the Niamey airport), Sect1-G simulates an average surface SW radiative forcing of $-34 \mathrm{~W} \mathrm{~m}^{-2}$ from dust and $-56 \mathrm{~W} \mathrm{~m}^{-2}$ from total aerosols at 12:00 UTC. The sensitivity simulation of Sect1-G with doubling of total biomass

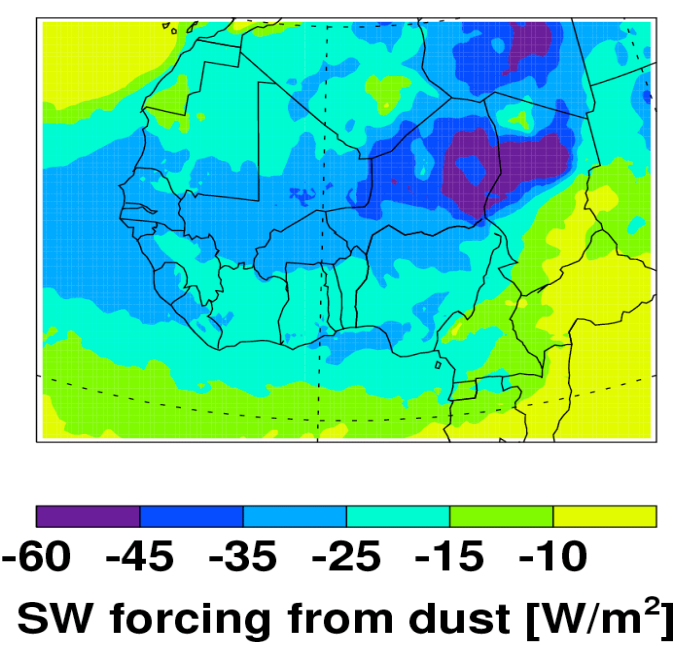

Fig. 12. Clear-sky surface SW dust radiative forcing at 12:00 UTC over North Africa for the simulation period estimated from the WRF-Chem simulations in the Sect1-G case. The SW dust radiative forcing is estimated by subtracting the result from the simulation without dust emissions from that from the simulation with dust emissions.

burning emissions simulates a surface $\mathrm{SW}$ radiative forcing of $-75 \mathrm{~W} \mathrm{~m}^{-2}$ from total aerosols, well consistent with the value of $-78 \mathrm{Wm}^{-2}$ retrieved by the AMF during the same period. Sect1-D simulates similar results as Sect1-G, while Modal1-G simulates $15 \%$ higher surface SW radiative forcing $\left(-39 \mathrm{~W} \mathrm{~m}^{-2}\right)$ from dust over the Sahel region, although it simulates similar spatial distribution of the forcing as Sect1-G. Modal2-G simulates similar surface SW radiative forcing from dust as Modal1-G.

\section{Conclusions}

In this study, two dust emission schemes (GOCART and DUSTRAN) are coupled with two aerosol models (MADE/SORGAM and MOSAIC) within the framework of the WRF-Chem model to investigate the modeling sensitivities to dust emissions and aerosol size treatments in simulating mineral dust and its SW radiative forcing over North Africa. Two choices for the size distributions of emitted dust are also trailed in the MADE/SORGAM aerosol model with the GOCART scheme. The performance of the WRF-Chem model in simulating mineral dust and its SW radiative properties is evaluated over North Africa in this study for the first time. When compared to ground-based, aircraft, and satellite retrievals of AOD, aerosol extinction profiles, SSA, and SW aerosol heating rates, we find WRF-Chem with proper size-resolved dust emissions and aerosol size treatments well captures the features of measured dust SW radiative properties over North Africa, although the modeling results are 
sensitive to the differences in size distributions of emitted dust and the underlying aerosol size treatments.

Both dust emission schemes produce the same total dust emissions, after proper tuning of the $C$ parameter, during the simulation period (from 6 January to 5 February 2006) over North Africa. Because of the tuning of the $C$ parameter to make the model simulated AOD consistent with the measurements, the total amount of dust emissions is sensitive to the size distributions of emitted dust, which results in that the total emitted dust amount for the simulation period changes from $200 \mathrm{Tg}$ for the case with more larger dust particles to $124 \mathrm{Tg}$ for the case with more smaller dust particles. The two schemes also simulate similar temporal evolution of dust emissions, although they were developed with different formulas. The spatial distributions of dust emissions from the two schemes are generally consistent but the DUSTRAN scheme simulates more dust emissions over the west coast of North Africa, resulting in higher dust concentrations in the outflows over North Atlantic. The simulated dust concentration is also sensitive to the size distributions of emitted dust. In order to simulate similar AOD, the model with more dust particles emitted into the submicron regime (radius $<1 \mu \mathrm{m}$ ) requires $40 \%$ less of emitted total dust mass and hence simulates $14 \%$ lower near-surface $(<1 \mathrm{~km})$ dust concentrations on domain average. However, it's noteworthy that the change of the size distribution of emitted dust in this study does not significantly change the spatial distribution of the dust SW radiative forcing and also the optical properties of dust (e.g., SSA).

The numerical representation of the aerosol size distribution has a larger influence on the evolution of the dust size distribution. In simulations using the same emission scheme and initial (emitted) dust size distribution, the modal approach of MADE/SORGAM aerosol model retains 25\% more fine dust particles $(r<1.25 \mu \mathrm{m})$ but $8 \%$ less coarse dust particles $(1.25 \mu \mathrm{m}<r<5 \mu \mathrm{m})$ than the sectional approach of MOSAIC aerosol model, leading to worse agreement with the DABEX measured dust size distribution. Consequently, the MADE/SORGAM aerosol model simulates $12 \%$ higher aerosol extinction coefficient, up to $13 \%$ lower SW dust heating rate, and $15 \%$ higher surface SW radiative forcing from dust than does the MOSAIC aerosol model over the Sahel region. However, it is noteworthy that the two aerosol models simulate similar mass concentrations for dust particles in the whole size range $(r<5 \mu \mathrm{m})$, which may indicate that the dust burden is mainly determined by the dust emission and dry deposition processes in the model during the dry season near the dust source region.

Through comparing with various measurements, Sect1-G simulates the best results among the different model cases. During the simulation period, the Sect1-G simulation show that mineral dust increases AOD by more than a factor of 2 , heats the lower atmosphere $(1-3 \mathrm{~km})$ with a maximum rate of $0.8 \pm 0.5 \mathrm{~K} \mathrm{day}^{-1}$ (the variation is due to the uncertainty of $n_{\mathrm{i}}$ of mineral dust) below $1 \mathrm{~km}$ at 08:00-12:00 UTC, and reduces the downwelling SW radiation at the surface by up to $58 \mathrm{~W} \mathrm{~m}^{-2}$ at 12:00 UTC over the Sahel region. On domain average, mineral dust heats the lower atmosphere with an average rate of $0.5 \pm 0.2 \mathrm{~K} \mathrm{day}^{-1}$ and reduces the downwelling SW radiation at the surface by $22 \mathrm{~W} \mathrm{~m}^{-2}$. The mineral dust warms the atmosphere but cools the land surface, which could significantly modulate the stability of the atmosphere over North Africa (Tulet et al., 2008).

Overall, the analysis of the WRF-Chem simulated results with available measurements highlights the importance of including the radiative impact of mineral dust to study regional climate over North Africa. Even if some previous papers using both regional and global models have been published on this subject, our study presents not only modeling of radiative forcing of mineral dust over North Africa but also its sensitivities to size-resolved dust emissions and aerosol size treatments to elucidate modeling uncertainties. Compared to other models in previous studies (e.g., MetUM model in Milton et al., 2008; MesoNH model in Tulet et al., 2008; Oslo CTM2 model in Myhre et al., 2008; RegCM3 model in Santese et al. 2010), WRF-Chem captures not only the spatial variability but also the size distribution and vertical profile of mineral dust over North Africa. The promising performance of WRF-Chem in simulating mineral dust and its radiative properties provides confidence to use the model for regional climate application over North Africa. Although the indirect effect of mineral dust is not investigated (not important in the dry season) and the longwave direct radiative effect is not yet implemented in the model, we plan to conduct long-term multi-year simulations using WRF-Chem in the near future that include longwave radiative effect and indirect effect of mineral dust to fully understand the regional climate impact of mineral dust over North Africa for both dry and wet seasons.

Acknowledgements. We thank Yun Qian for his internal review in PNNL. This paper benefited from valuable comments and suggestions by two anonymous reviewers. This study is supported by the Department of Energy Climate Change Prediction Program (CCPP) Investigations on the Magnitude and Probabilities of Abrupt Climate TransitionS (IMPACTS) project. Pacific Northwest National Laboratory is operated for the US DOE by Battelle Memorial Institute under contract DE-AC06-76RLO330 1830. A portion of the research was performed using EMSL, a national scientific user facility sponsored by the Department of Energy's Office of Biological and Environmental Research and located at Pacific Northwest National Laboratory.

Edited by: Y. Balkanski

\section{References}

Ackermann, I. J., Hass, H., Memmesheimer, M., Ebel, A., Binkowski, F. S., and Shankar, U.: Modal aerosol dynamics model for Europe: Development and first applications, Atmos. Environ., 32, 2981-2999, 1998. 
Allwine, K. J., Rutz, F. C., Shaw, W. J., Rishel, J. P., Fritz, B. G., Chapman, E. G., Hoopes, B. L., and Seiple, T. E.: DUSTRAN 1.0 User's Guide: A GIS-Based Atmospheric Dust Dispersion Modeling System. Technical Report PNNL-16055, Pacific Northwest National Laboratory, Richland, Washington, 2006.

Bagnold, R. A.: The physics of Blown sand and Desert Dunes, Methuen, New York, 10, 265 pp., 1941.

Balkanski, Y., Schulz, M., Claquin, T., and Guibert, S.: Reevaluation of Mineral aerosol radiative forcings suggests a better agreement with satellite and AERONET data, Atmos. Chem. Phys., 7, 81-95, doi:10.5194/acp-7-81-2007, 2007.

Barnard, J. C., Fast, J. D., Paredes-Miranda, G., Arnott, W. P., and Laskin, A.: Technical Note: Evaluation of the WRF-Chem "Aerosol Chemical to Aerosol Optical Properties" Module using data from the MILAGRO campaign, Atmos. Chem. Phys., 10, 7325-7340, doi:10.5194/acp-10-7325-2010, 2010.

Bellouin, N., Boucher, O., Haywood, J. M., Johnson, C., Jones, A., Rae, J., and Woodward, S.: Improved representation of aerosols for Had-GEM2, Tech. Note 73, Hadley Cent., Exeter, UK, 2007.

Binkowski, F. S. and Shankar, U.: The regional particulate matter model: 1. Model description and preliminary results, J. Geophys. Res., 100, 26191-26209, 1995.

Ackermann, I. J., Hass, H., Memmesheimer, M., Ebel, A., Binkowski, F. S., and Shankar, U.: Modal aerosol dynamics model for Europe: development and first applications, Atmos. Environ., 32, 2981-2999, 1998.

Chin, M., Diehl, T., Ginoux, P., and Malm, W.: Intercontinental transport of pollution and dust aerosols: implications for regional air quality, Atmos. Chem. Phys., 7, 5501-5517, doi:10.5194/acp7-5501-2007, 2007.

Darmenova, K., Sokolik, I. N., Shao, Y., Marticorena, B., and Bergametti, G.: Development of a physically based dust emission module within the Weather Research and Forecasting (WRF) model: Assessment of dust emission parameterizations and input parameters for source regions in Central and East Asia, J. Geophys. Res., 114, D14201, doi:10.1029/2008JD011236, 2009.

D'almeida, G. and Schutz, L.: Number, Mass and Volume Distribution of Mineral Aerosol and Soils of the Sahara, American Meteorology Society, 223-243, 1983.

Dentener, F., Kinne, S., Bond, T., Boucher, O., Cofala, J., Generoso, S., Ginoux, P., Gong, S., Hoelzemann, J. J., Ito, A., Marelli, L., Penner, J. E., Putaud, J.-P., Textor, C., Schulz, M., van der Werf, G. R., and Wilson, J.: Emissions of primary aerosol and precursor gases in the years 2000 and 1750 prescribed data-sets for AeroCom, Atmos. Chem. Phys., 6, 4321-4344, doi:10.5194/acp6-4321-2006, 2006.

Diner, D., Beckert, J., Reilly, T., Bruegge, C., Conel, J., Kahn, R., Martonchik, J., Ackerman, T., Davies, R., Gerstl, S., et al.: Multi-angle Imaging SpectroRadiometer (MISR) instrument description and experiment overview, IEEE T. Geosci. Remote, 36, 1072-1087, 1998.

Diner, D. J., Abdou, W. A., Bruegge, C. J., Conel, J. E., Crean, K. A., Gaitley, B. J., Helmlinger, M. C., Kahn, R. A., Martonchik, J. V., and Pilorz, S. H.: MISR aerosol optical depth retrievals over southern Africa during the SAFARI-2000 dry season campaign, Geophys. Res. Lett., 28, 3127-3130, 2001.

Dubovik, O. and King, M. D.: A ?exible inversion algorithm for retrieval of aerosol optical properties from sun and sky radiance measurements, J. Geophys. Res., 105, 20673-20696, 2000.

Dubovik, O., Holben, B., Eck, T. F., Smirnov, A., et al.: Variability of absorption and optical properties of key aerosol types observed in worldwide locations, J. Atmos. Sci., 59, 590-608, 2002.

Evan, A. T., Vimont, D. J., Heidinger, A. K., Kossin, J. P., and Bennartz, R.: The role of aerosols in the evolution of tropical North Atlantic Ocean temperature anomalies, Science, 324, 778781, 2009.

Fast, J. D, Gustafson Jr., W. I., Easter, R. C., Zaveri, R. A., Barnard, J. C., Chapman, E. G., and. Grell, G. A.: Evolution of ozone, particulates, and aerosol direct forcing in an urban area using a new fully-coupled meteorology, chemistry, and aerosol model, J. Geophys. Res., 111, D21305, doi:10.1029/2005JD006721, 2006.

Fast, J., Aiken, A. C., Allan, J., Alexander, L., Campos, T., Canagaratna, M. R., Chapman, E., DeCarlo, P. F., de Foy, B., Gaffney, J., de Gouw, J., Doran, J. C., Emmons, L., Hodzic, A., Herndon, S. C., Huey, G., Jayne, J. T., Jimenez, J. L., Kleinman, L., Kuster, W., Marley, N., Russell, L., Ochoa, C., Onasch, T. B., Pekour, M., Song, C., Ulbrich, I. M., Warneke, C., WelshBon, D., Wiedinmyer, C., Worsnop, D. R., Yu, X.-Y., and Zaveri, R.: Evaluating simulated primary anthropogenic and biomass burning organic aerosols during MILAGRO: implications for assessing treatments of secondary organic aerosols, Atmos. Chem. Phys., 9, 6191-6215, doi:10.5194/acp-9-6191-2009, 2009.

Flaounas, E., Coll, I., Armengaud, A., and Schmechtig, C.: The representation of dust transport and missing urban sources as major issues for the simulation of PM episodes in a Mediterranean area, Atmos. Chem. Phys., 9, 8091-8101, doi:10.5194/acp-9-80912009, 2009.

Forster, P., Ramaswamy, V., Artaxo, P., Berntsen, T., Betts, R., et al.: Changes in atmospheric constituents and in radiative forcing, in: Climate change 2007: The physical science basis. Contribution of Working Group I to the Fourth Assessment Report of the Intergovernmental Panel on Climate Change Cambridge University Press, edited by: Solomon, S., Qin, D., Manning, M., Chen, Z., Marquis, M., et al., United Kingdom and New York, NY, USA, 2007.

Ghan, S., Laulainen, N., Easter, R., Wagener, R., Nemesure, S., Chapman, E., Zhang, Y., and Leung, R.: Evaluation of aerosol direct radiative forcing in MIRAGE, J. Geophys. Res., 106, 52955316, 2001.

Ginoux, P., Chin, M., Tegen, I., Prospero, J. M., Holben, B., Dubovik, O., and Lin, S.: Sources and distributions of dust aerosols simulated with the GOCART model, J. Geophys. Res., 106, 20225-20273, 2001.

Gong, S. L., Zhang, X. Y., Zhao, T. L., McKendry, I. G., Jaffe, D. A., and Lu, N. M.: Characterization of soil dust aerosol in China and its transport and distribution during 2001 ACE-Asia: 2. Model simulation and validation, J. Geophys. Res., 108, 4262, doi:10.1029/2002JD002633, 2003.

Greed, G., Haywood, J. M., Milton, S., Keil, A., Christopher, S., Gupta, P., and Highwood, E. J.: Aerosol optical depths over North Africa: 2. Modeling and model validation, J. Geophys. Res., 113, D00C05, doi:10.1029/2007JD009457, 2008.

Grell, G. A., Peckham, S. E., Schmitz, R., and McKeen, S. A., Frost, G., Skamarock, W. C., and Eder, B.: Fully coupled "online" chemistry within the WRF model, Atmos. Environ., 39, 69576976, 2005. 
Gustafson, W. I., Chapman, E. G., Ghan, S. J., Easter, R. C., and Fast, J. D.: Impact on modeled cloud characteristics due to simplified treatment of uniform cloud condensation nuclei during NEAQS 2004, Geophys. Res. Lett., 34, L19809, doi:10.1029/2007GL0300321, 2007.

Haywood, J., Francis, P., Osborne, S., Glew, M., Loeb, N., Highwood, E., Tanre, D., Myhre, G., Formenti, P., and Hirst, E.: Radiative proper ties and direct radiative effect of Saharan dust measured by the C-130 aircraft during Saharan Dust Experiment (SHADE), 1: Solar spectrum, J. Geophys. Res., 108, 8577, doi:10.1029/2002JD002687, 2003.

Haywood, J. M., Pelon, J., Formenti, P., Bharmal, N., Brooks, M., Capes, G., et al.: Overview of the Dust and Biomass-burning Experiment and African Monsoon Multidisciplinary Analysis Special Observing Period-0, J. Geophys. Res., 113, D00C17, doi:10.1029/2008JD010077, 2008.

Holben, B. N., Eck, T. F., Slutsker, I., Tanr' e, D., Buis, J. P., Stezer, A., Vermote, E., Reagan, Y., Kaufman, U. J., Nakajima, T., Lavenu, F., Jankowiak, I., and Smirnov, A.: AERONET-A federated instrument network and data archive for aerosol characterization, Remote Sens. Environ., 66, 1-16, 1998.

Holben, B. N., Tanre, D., Smirnov, A., ECK T. F., Slutsker, I., Abuhassan, N., et al.: An emerging ground-based aerosol climatology: Aerosol optical depth from AERONET, J. Geophys. Res., 106, 12067-12097, 2001.

Hsu, N. C., Tsay, S., King, M., and Herman, J. R.: Deep blue retrievals of Asian Aerosol Properties during ACE-Asia, IEEE T. Geosci. Remote, 44, 3180, 2006.

IPCC: The Physical Science Basis. Contribution of Working Group I to the Fourth Assessment Report of the Intergovernmental Panel on Climate Change Cambridge University Press, Cambridge, United Kingdom and New York, NY, USA, 2007.

Johnson, D. W., Osborne, S. R., Wood, R., Suhre, K., Johnson, R., et al.: Observations of the evolution of the aerosol, cloud and boundary-layer characteristics during the 1st ACE-2 Lagrangian experiment, Tellus B, 52, 348-374, 2000.

Johnson, B. T., Heese, B., McFarlane, S. A., Chazette, P., Jones, A., and Bellouin, N.: Vertical distribution and radiative effects of mineral dust and biomass burning aerosol over West Africa during DABEX, J. Geophys. Res., 113, D00C12, doi:10.1029/2008JD009848, 2008a.

Johnson, B. T., Osborne, S. R., Haywood, J. M., and Harrison, M.: Aircraft measurements of biomass burning aerosol over West Africa during DABEX, J. Geophys. Res., 113, D00C06, doi:10.1029/2007JD009451, 2008b.

Kalashnikova, O. V. and Sokolik, I. N.: Modeling the radiative properties of nonspherical soil-derived mineral aerosols, J. Quant. Spectrosc. Ra., 87, 137-166, 2004.

Kandler, K., Benker, N., Bundke, U., Cuevas, E., Ebert, M., Knippertz, P., Rodriguez, S., Schutz, L., and Weinbruch, S.: Chemical composition and complex refractive index of Saharan Mineral Dust at Izana, Tenerife (Spain) derived by electron microscopy, Atmos. Environ., 41, 8058-8074, 2007.

Kassianov, E. I., Flynn, C. J., Ackerman, T. P., and Barnard, J. C.: Aerosol single-scattering albedo and asymmetry parameter from MFRSR observations during the ARM Aerosol IOP 2003, Atmos. Chem. Phys., 7, 3341-3351, doi:10.5194/acp-7-3341-2007, 2007.

Kaufman, Y. J., Tanre, D., Remer, L. A., Vermote, E. F., Chu, A., and Holben, B. N.: Operational remote sensing of tropospheric aerosol over land from EOS moderate resolution imaging spectroradiometer, J. Geophys. Res., 102, 17051-17067, 1997.

Lau, K. M., Kim, K. M., Sud, Y. C., and Walker, G. K.: A GCM study of the response of the atmospheric water cycle of West Africa and the Atlantic to Saharan dust radiative forcing, Ann. Geophys., 27, 4023-4037, doi:10.5194/angeo-27-40232009, 2009.

Leung, L. R., Kuo, Y. H., and Tribbia., J.: Research Needs and Directions of Regional Climate Modeling Using WRF and CCSM, B. Am. Meteorol. Soc., 87(12), 1747-1751, 2006.

Levy, R. C., Remer, L. A., Tanre, D., Kaufman, Y. J., Ichoku, C., Holben, B. N., Livingston, J. M., Russell, P. B., and Maring H.: Evaluation of the Moderate-Resolution Imaging Spectroradiometer (MODIS) retrievals of dust aerosol over the ocean during PRIDE, J. Geophys. Res., 108, D198594, doi:10.1029/2002JD002460, 2003.

Martonchik, J. V., Diner, D. J., Kahn, R., and Gaitley, B.: Comparison of MISR and AERONET aerosol optical depths over desert sites, Geophys. Res. Lett., 31, L16102, doi:10.1029/2004GL019807, 2004.

McConnell, C. L., Formenti, P., Highwood, E. J., and Harrison, M. A. J.: Using aircraft measurements to determine the refractive index of Saharan dust during the DODO Experiments, Atmos. Chem. Phys., 10, 3081-3098, doi:10.5194/acp-10-3081-2010, 2010.

McFarlane, S. A., Kassianov, E. I., Barnard, J., Flynn, C., and Ackerman, T. P.: Surface shortwave aerosol radiative forcing during the Atmospheric Radiation Measurement Mobile Facility deployment in Niamey, Niger, J. Geophys. Res., 114, D00E06, doi:10.1029/2008JD010491, 2009.

McKeen, S. A., Wotawa, G., Parrish, D. D., Holloway, J. S., Buhr, M. P., Hubler, G., Fehsenfeld, F. C., and Meagher, J. F.: Ozone production from Canadian wildfires during June and July of 1995, J. Geophys. Res., 107(D14), 4192, doi:10.1029/2001JD000697, 2002.

Miller, R. L., Tegen, I., and Perlwitz, J.: Surface radiative forcing by soil dust aerosols and the hydrologic cycle, J. Geophys. Res., 109, D04203, doi:10.1029/2003JD004085, 2004.

Miller, R. L., Cakmur, R. V., Perlwitz, J., Geogdzhayev, I. V., Ginoux, P., Koch, D., Kohfeld, K. E., Prigent, C., Ruedy, R., Schmidt, G. A., and Tegen, I.: Mineral dust aerosols in the NASA Goddard Institute of Space Sciences ModelE atmospheric general circulation model, J. Geophys. Res., 111, D06208, doi:10.1029/2005JD005796, 2006.

Miller, M. A. and Slingo, A.: The ARM Mobile Facility and its first international deployment: Measuring radiative flux divergence in West Africa, B. Am. Meteorol. Soc., 88, 1229-1244, doi:10.1175/BAMS-88-8-1229, 2007.

Milton, S. F., Greed, G., Brooks, M. E., Haywood, J., Johnson, B., Allan, R. P., Slingo, A., and Grey, W. M.: Modeled and observed atmospheric radiation balance during the West African dry season: Role of mineral dust, biomass burning aerosol, and surface albedo, J. Geophys. Res., 113, D00C02, doi:10.1029/2007JD009741, 2008.

Moulin, C., Lambert, C. E., Dulac, F., and Dayan, U.: Control of atmospheric export from North Africa by the North Atlantic Oscillation, Nature, 397, 691-694, doi:10.1038/42679, 1997.

Myhre, G., Hoyle, C. R., Berglen, T. F., Johnson, B. T., and 
Haywood, J. M.: Modeling of the solar radiative impact of biomass burning aerosols during the Dust and Biomassburning Experiment (DABEX), J. Geophys. Res., 113, D00C16, doi:10.1029/2008JD009857, 2008.

Nickovic, S., Kallos, G., Papadopoulos, A., and Kakaliagou, O.: A model for prediction of desert dust cycle in the atmosphere, J. Geophys. Res., 106, 18113-18129, 2001.

Olson, J. S.: World ecosystems (WE1.4). Digital raster data on a 10-minute Cartesian orthonormal geodetic 1090x2160 grid, in: Global Ecosystems Database, Version 2.0. Boulder, Colorado, 1992.

Osborne, S. R., Johnson, B. T., Haywood, J. M., Baran, A. J., Harrison, A. J., and McConnell, C. L.: Physical and optical properties of mineral dust aerosol during the Dust and Biomass-burning Experiment, J. Geophys. Res., 113, D00C03, doi:10.1029/2007JD009551, 2008.

Otto, S., Bierwith, E., Weinzierl, B., Kandler, K., Esselborn, M., Tesche, M., Schladitz, A., Wendisch, M., and Trautmann, T.: Solar radiative effects of a Saharan dust plume observed during SAMUM assuming spheroidal model particles, Tellus B, 61(1), 270-296, 2009.

Patterson, E. M., Filette, D. A., and Stockton, B. H.: Complex index of refraction between 300 and $700 \mathrm{~nm}$ for Saharan aerosols, J. Geophys. Res., 82, 3153-3160, 1977.

Petzold, A., Rasp, K., Weinzierl, B., Esselborn, M., Hamburger, T., Dornbrack, A., Kandler, K., Schutz, L., Knippertz, P., Fiebig, M., and Virkkula, A.: Saharan dust absorption and refractive index from aircraft-based observations during SAMUM 2006, Tellus B, 61(1), 118-130, 2009.

Qian, Y, Gustafson Jr., W. I., Leung, L. Y., and Ghan, S.: Effects of soot-induced snow albedo change on snowpack and hydrological cycle in western United States based on Weather Research and Forecasting chemistry and regional climate simulations, J. Geophys. Res., 114, D03108, doi:10.1029/2008JD011039, 2009.

Ramanathan, V., Crutzen, P. J., Kiehl, J. T., and Rosenfeld, D.: Atmosphere-Aerosols, climate, and the hydrological cycle, Science, 294(5549), 2119-2124, 2001.

Randerson, J. T., Van der Werf, G. R., Giglio, L., Collatz, G. J., and Kasibhatla., P. S.: Global Fire Emissions Database, Version 2 (GFEDv2.1), available at: http://daac.ornl.gov/ from Oak Ridge National Laboratory Distributed Active Archive Center, Oak Ridge, Tennesse, USA, doi:10.3334/ORNLDAAC/849, 2005.

Redelsperger, J. L., Thorncroft, C. D., Diedhiou, A., Lebel, T., Parker, D. J., and Polcher, J.: African Monsoon Multidisciplinary Analysis: An international research project and field campaign, B. Am. Meteorol. Soc., 87, 1739-1746, doi:10.1175/BAMS-8712-1739, 2006.

Remer, L. A., Kaufman, Y. J., Tanre, D., Mattoo, S., Chu, D. A., Martins, J. V., Li, R., Ichoku, C., Levy, R. C., et al.: The MODIS aerosol algorithm, products and validation, J. Atmos. Sci., 62, 947-973, 2005.

Santese, M., Perrone, M. R., Zakey, A. S., De Tomasi, F., and Giorgi, F.: Modeling of Saharan dust outbreaks over the Mediterranean by RegCM3: case studies, Atmos. Chem. Phys., 10, 133156, doi:10.5194/acp-10-133-2010, 2010.

Schell, B., Ackermann, I. J., Hass, H., Binkowski, F. S., and Ebel, A.: Modeling the formation of secondary organic aerosol within a comprehensive air quality modeling system, J. Geophys. Res., 106, 28275-28293, 2001.
Skamarock, W. C., Klemp, J. B., Dudhia, J., Gill, D. O., Barker, D. M., Duda, M. G., Huang, X., Wang, W., and Powers, J. G.: A description of the advanced research WRF version 3, NCAR Tech. Note, NCAR/TN-475+STR, 8 pp., Natl. Cent. for Atmos. Res., Boulder, Colo., available at: http://www.mmm.ucar.edu/ wrf/users/docs/arw_v3.pdf, 2008.

Shaw, W., Allwine, K. J., Fritz, B. G., Rutz, F. C., Rishel, J. P., and Chapman, E. G.: An evaluation of the wind erosion module in DUSTRAN, Atmos. Environ., 42, 1907-1921, 2008.

Sokolik, I. N., Toon, O. B., and Bergstrom, R. W.: Modelling the radiative characteristics of air-airborne mineral aerosols at infrared wavelengths, J. Geophys. Res., 103, 8813-8826, 1998.

Sow, M., Alfaro, S. C., Rajot, J. L., and Marticorena, B.: Size resolved dust emission fluxes measured in Niger during 3 dust storms of the AMMA experiment, Atmos. Chem. Phys., 9, 38813891, doi:10.5194/acp-9-3881-2009, 2009.

Stockwell, W. R., Middleton, P., Chang, J. S., and Tang, X.: The second generation regional acid deposition model chemical mechanism for regional air quality modeling, J. Geophys. Res., 95, 16343-16367, 1990.

Tegen, I. and Fung, I.: Modeling of mineral dust in the atmosphere: Sources, transport, and optical thickness, J. Geophys. Res., 99, 22897-22914, 1994.

Tegen, I. and Lacis, A. A.: Modeling of particle size distribution and its influence on the radiative properties of mineral dust aerosol, J. Geophys. Res., 101, 19237-19244, 1996.

Tegen, I., Hollrig, P., Chin, M., Fung, I., Jacob, D., and Penner, J.: Contribution of different aerosol species to the global aerosol extinction optical thickness: Estimates from model results, J. Geophys. Res., 102, 23895-23915, 1997.

Tulet, P., Mallet, M., Pont, V., Pelon, J., and Aaron, B.: The 713 March 2006 dust storm over West Africa: Generation, transport, and vertical stratification, J. Geophys. Res., 113, D00C08, doi:10.1029/2008JD009871, 2008.

Wang, W. and Liu, X.: Evaluating deep updraft formulation in NCAR CAM3 with high resolution WRF simulations during ARM TWP-ICE, Geophys. Res. Lett., 36, L04701, doi:10.1029/2008GL036692, 2009.

Zakey, A. S., Solmon, F., and Giorgi, F.: Implementation and testing of a desert dust module in a regional climate model, Atmos. Chem. Phys., 6, 4687-4704, doi:10.5194/acp-6-4687-2006, 2006.

Zaveri, R. A. and Peters, L. K.: A new lumped structure photochemical mechanism for large-scale applications, J. Geophys. Res., 104, 30387-30415, 1999.

Zaveri, R. A., Easter, R. C., Fast, J. D., and Peters, L. K.: Model for simulating aerosol interactions and chemistry (MOSAIC), J. Geophys. Res., 113, D13204, doi:10.1029/2007JD008792, 2008.

Zender, C. S., Bian, H., and Newman, D.: Mineral Dust Entrainment and Deposition (DEAD) model: Description and 1990s dust climatology, J. Geophys. Res., 108, 4416, doi:10.1029/2002JD002775, 2003.

Zhang Y., Duliere, V., Mote, P. W., Salathe Jr., E. P.: Evaluation of WRF and HadRM Mesoscale Climate Simulations over the U.S. Pacific Northwest, J. Climate, 22, 5511-5526, doi:10.1175/2009JCLI2875.1, 2009. 